Maurice A. Deane School of Law at Hofstra University Scholarly Commons at Hofstra Law

Hofstra Law Faculty Scholarship

2011

\title{
Democracy at the Corner of First and Fourteenth: Judicial Campaign Spending and Equality
}

James Sample

Maurice A. Deane School of Law at Hofstra University

Follow this and additional works at: https://scholarlycommons.law.hofstra.edu/faculty_scholarship

\section{Recommended Citation}

James Sample, Democracy at the Corner of First and Fourteenth: Judicial Campaign Spending and Equality, 66 N.Y.U. Ann. Surv. Am. L. $727(2011)$

Available at: https://scholarlycommons.law.hofstra.edu/faculty_scholarship/493

This Article is brought to you for free and open access by Scholarly Commons at Hofstra Law. It has been accepted for inclusion in Hofstra Law Faculty Scholarship by an authorized administrator of Scholarly Commons at Hofstra Law. For more information, please contact lawcls@hofstra.edu. 


\title{
DEMOCRACY AT THE CORNER OF FIRST AND FOURTEENTH: JUDICIAL CAMPAIGN SPENDING AND EQUALITY
}

\author{
JAMES SAMPLE*
}

Save for the notorious crack/powder distinction, it's hard to think of a line that has been subjected to more withering criticism over the years than Buckley's expenditure/contribution distinction. ${ }^{1}$

-Pamela S. Karlan

In invalidating some of the existing checks on campaign spending, . . . the majority in Citizens United has signaled that the problem of campaign contributions in judicial elections might get considerably worse and quite soon.... [I] f both [unions and corporations] unleash their campaign spending monies without restrictions, then I think mutually-assured destruction is the most likely outcome. ${ }^{2}$

- Justice Sandra Day O'Connor

\section{ABSTRACT}

The Supreme Court recently decided in Caperton v. A.T. Massey Coal Co. that substantial independent expenditures in support of a judicial candidate present threats to judicial impartiality similar to those posed by direct contributions. This Article posits that the Caperton holding, guaranteeing due process of law in state courts, presents a compelling state interest justifying the regulation of spending in judicial elections.

* Associate Professor of Law, Hofstra University School of Law; J.D., Columbia Law School, 2003; B.A., Boston College, 1995. Sincere thanks to William Andersen, Mary Clark, Amanda Frost, Rick Hasen, Michael Gerhardt, Charlie Geyh, Justin Levitt, Darryl Stein, and Jay Tidmarsh for helpful comments. By way of disclosure, I served as counsel on certiorari and merits stage amicus briefs in support of the petitioners in Caperton v. A.T. Massey Coal Co., 129 S. Ct. 2252 (2009).

1. Pamela S. Karlan, New Beginnings and Dead Ends in the Law of Democracy, 68 OHo St. L.J. 743, 747 (2007).

2. Adam Liptak, Former Justice O'Connor Sees Ill in Election Finance Ruling, N.Y. Times, Jan. 27, 2010, at A16, available at http://www.nytimes.com/2010/01/27/ us/politics/27judge.html. 
The Supreme Court's landmark decision in Buckley v. Valeo is understood to hold that only an "anti-corruption" rationale can justify campaign finance regulations. Buckley drew a rigid distinction between political campaign "expenditures" and "contributions," holding that the anti-cormuption interest justifies regulating only the latter. This Article asserts that the contribution-expenditure distinction is particularly counterproductive in the judicial election context, precisely because due process of law is fundamental to the courts to a degree unmatched by the risk of corruption in the constituent branches.

The Article starts by documenting the exponential increases in campaign cash and the newly central roles played by massive, and often highly secretive, independent expenditure campaigns in high-profile judicial elections over the past decade. It then asserts that Caperton's approach is therefore a refreshing rejection of formalism in these compelling and new circumstances. If embraced more widely, the norms that inform the Caperton approach can mitigate the emerging constitutional crisis in our state courts that Justice O'Connor, among others, so aptly describes.

\section{TABLE OF CONTENTS}

Introduction .................................. 729

I. The Contributions vs. Expenditures Conundrum .... 733

A. Buckley and the Birth of a Distinction ......... 733

B. The Unintended Consequences of Buckley ....... 735

C. The Rising Tide of Independent Expenditures... 738

II. Campaign Cash and the New Politics of Judicial

Elections .............................. 744

A. Everything's Bigger in Texas.............. 745

B. 2000-2009: Cash in the Courtroom Goes National .......................... 746

C. There is no truth. There is only perception..... 749

D. Super Spenders...................... 750

E. Case Study: Avery v. State Farm .............. 752

III. "Caperton Contributions" and Due Process ......... 756

A. Facts That Push Formalism Beyond Its Limits .... 757

B. Caperton and the Buckley Conundrum ......... 760

1. Framing the Issue Before the Court ...... 760

2. Sub Silentio Genius.................. 765

IV. Judicial Campaign Expenditure Limits: An Exception Born of Exceptionalism ...................... 774

A. The Due Process Interest in Limiting Judicial

Campaign Finance.................... 774

B. Expenditure Limits and the Equality Rationale .. 778

V. Conclusion ......................... 780 


\section{INTRODUCTION}

On June 8, 2009, Professor Rick Hasen of Loyola Law School, indisputably among the nation's leading election law scholars, did something rather remarkable on his widely read Election Law blog: he suggested that a Supreme Court Justice had made an inadvertent error in an opinion, radically changing its meaning. ${ }^{3}$ His post called attention to Caperton v. A.T. Massey Coal Co. ${ }^{4}$ which was decided that day and involved the constitutional standards dictating when a judge must recuse himself based on campaign contributions. Hasen found it very curious, "given the key distinction in campaign finance law between contributions and expenditures,"5 that Justice Kennedy framed the issue as follows: "The basis for the motion was that the justice had received campaign contributions in an extraordinary amount from, and through the efforts of, the board chairman and principal officer of the corporation found liable for the damages." 6 Professor Hasen suggested that this was an unwitting error: "Perhaps this inadvertent equating of contributions and expenditures will disappear when this opinion is finalized for the U.S. Reports."7

Not so. Rather than imagining away a key aspect of the Court's opinion in Caperton as a scrivener's error, the Court should be taken at its word: at least with respect to judicial elections, substantial independent expenditures can present a significant risk of corruption and a significant challenge to due process, both of which justify greater state regulation of campaign expenditures. Indeed, as Justice Stevens wrote one year later, "In Caperton ... we accepted the premise that, at least in some circumstances, independent expenditures on candidate elections will raise an intolerable specter of quid pro quo corruption." 8 Justice Stevens makes explicit what this Article asserts was implicit in Caperton, when he notes that " $[t]$ he reason the Court so thoroughly conflated expenditures and contributions, one assumes, is that it realized that some expenditures may be functionally equivalent to contributions." 9

3. Rick Hasen, Initial Thoughts on Caperton v. Massey: First Meaningful Constitutional Limits on Excess of Judicial Elections, Election LAW Blog (June 8, 2009, 7:58 AM), http://electionlawblog.org/archives/013784.html.

4. 129 S. Ct. 2252 (2009).

5. Hasen, supra note 3.

6. Id. (quoting Caperton, $129 \mathrm{~S}$. Ct at 2256-57) (emphasis added by Hasen)

7. Id.

8. Citizens United v. FEC., 130 S. Ct. 876, 967 (2010) (Stevens, J., concurring in part and dissenting in part).

9. Id. at 968 . 
Love them or loathe them, judicial elections are here to stay. Accordingly, lest due process be reduced to a mere parchment promise, scholars, lawyers, and judges can no longer afford the luxury of further indulging in the perpetual, exclusively binary love/ loathe debate over whether judicial appointment or election is preferable. ${ }^{10}$ Instead, it is increasingly clear that the realities reflected in the two quotes above are now on a collision course. This Article argues that the decision in Caperton suggests a way forward. Caperton recognizes the possibility for influence and the perception thereof in the judicial electoral context; and, by implication, supports the notion that the cognate threat to due process is so far heightened as to create an independent state interest in regulating not only campaign contributions, but also expenditures. Independent expenditures in the context of judicial elections are thus regulable in this view.

In the past decade, "in high court contests across America, cash has become king. Would-be justices must raise millions from individuals and groups with business before the courts. Millions more are spent by political parties and special-interest groups, much of it undisclosed." 11 This Author has previously asserted that Caperton "is correct in result; correct in its narrowness; and correct in calling on courts to be more rigorous in recusal than due process requires." 12 This Article goes further by arguing that one of the most controversial aspects of Caperton-the manner in which Justice Kennedy's opinion for the majority conflates direct campaign contributions and independent expenditures for the purposes of due process analysis-is specifically among the most compelling aspects of the decision and provides a model for prospective judicial campaign reform.

Part I of this Article summarizes the consequences of two enduring aspects of the Court's landmark decision in Buckley $v$. Valeo: ${ }^{13}$ the contribution-expenditure distinction noted above and the rejection of state interests in regulating campaign finance other than that in limiting corruption or the appearance of corruption. It

10. See Charles Gardner Geyh, The Endless Judicial Selection Debate and Why it Matters for Judicial Independence, 21 GEO. J. LEGAL ETHICs 1259, 1279 (2008) (noting that changing election systems "can be a worthy goal and one well worth pursuing ... but not at the expense of ignoring shorter-term remedies that can make a bad system better in the interim").

11. James Sample et al., The New Politics of Judicial Elections, 2000-2009: Decade of Change 5 (Charles Hall, ed. 2010).

12. James Sample, Caperton: Correct Today, Compelling Tomorrow, 60 Syracuse L. REV. 293, 293 (2010).

13. 424 U.S. 1 (1976). 
also describes the effects of these two aspects of Buckley, including the rise of independent expenditures. As Professor Neuborne puts it, "[I]n simple economic terms, the Buckley Court limited supply (contributions), while leaving demand (expenditures) free to grow without limit. The predictable effect has been to increase the pressures on candidates to satisfy the ever-increasing demand for campaign cash." 14

Against a background of that supply-demand asymmetry-arguably counterproductive enough as it is in the legislative and executive contexts-Part II of this Article examines the exponential increases in campaign cash and the newly central roles played by independent expenditures in high-profile judicial elections over the past decade. The dynamics of increasing expenditures and contributions in judicial elections ${ }^{15}$ were not at issue in Buckley, a case that involved federal legislation applicable to Congressional and Presidential contests. Moreover, this Article notes that those dynamics were utterly inconceivable when Buckley was decided in 1974, a time when judicial elections were generally uncontested and were at most low-salience, low-cost, and sleepy affairs.

Part III, picking up on Justice Stevens's assertions, first coins the term "Caperton contributions" to describe the equation of independent expenditures with contributions in the judicial elections context. Then, in light of the new normal in judicial elections, Part III asserts that Justice Kennedy's sub silentio treatment of independent expenditures as contributions is a refreshing rejection of formalism in a circumstance where, if the rigid distinction had been controlling, the focus of analysis would have been $\$ 1000$ in campaign contributions as opposed to $\$ 3$ million in expenditure support. It is worth noting that, without Justice Kennedy's vote, that precise head-in-the-sand result would have obtained in the Supreme Court. Although the majority opinion in Caperton does not elaborate on the reasoning behind the interchangeable use of the terms, there can be little doubt that the Justices in the majority, all of whom are exceedingly well versed in the Court's historical and recent campaign finance jurisprudence, fully intended the conflation. The Court's approach to the distinction was not only correct on the facts, it was also a constitutionally and structurally appropriate mode of analysis that accommodated both the First Amendment and the Due Process Clause in the judicial campaign context.

14. Burt Neuborne, Campaign Finance Reform \& The Constitution: A CRITICAI LoOK AT Buckley v. Valeo 18 (Brennan Center for Justice 1998), available at http://brennan.3cdn.net/f124fc7ebf928fb019_hqm6bn3w0.pdf.

15. See SAmple ET AL., supra note 11. 
Caperton reflects a realpolitik grounding that ought to extend to making the constitutional case for a whole range of legitimate judicial campaign finance regulation, including, for instance, so-called "trigger matching funds" 16 in response to independent expenditures supportive of a candidate's adversary in the growing number of states adopting public financing systems for their elected judiciaries.

Extending the theoretical premise, Part IV argues that not only is the formal dichotomy of unlimited expenditures and limited contributions a particularly bad fit for modern-day judicial elections; the long-disfavored equality or "leveling" rationale is an especially good fit for these examples (for better or worse) of American exceptionalism. ${ }^{17}$ Furthermore, this Article asserts that Cass Sunstein's argument that " $[i] \mathrm{n}$ rejecting the claim that controls on financial expenditures could be justified as a means of promoting political equality, .. . Buckley might well be seen as the modern-day analogue of the infamous and discredited case of Lochner $v$. New York"18 applies a fortiori to the rejection of expenditure limits in campaigns for judicial offices. Unlike their legislative and executive branch counterparts, judicial offices constitutionally entail both structural and individual rights commitments to impartiality and equality under law. Accordingly, the compelling state interest in the reality and appearance of impartial courts, and, in extreme instances, individual litigants' due process rights, should be construed to meet the exacting strict scrutiny analysis required for expenditure limitations to pass constitutional muster under the Buckley framework.

16. Also termed "rescue funds" or "fair-fight funds," these additional public grants are "triggered" when a privately funded opponent's or independent speaker's expenditures exceed a designated monetary threshold. See Memorandum from the Brennan Center of Justice, H.R. 1826: A Response (Dec. 17, 2009), available at http://www.brennancenter.org/content/resource/h.r._1826_a_re sponse/. See also M. Colleen Connor, Raising Arizona: Strengthening Express Advocacy Regulation Through the Citizens Clean Elections Act, 34 ARIz. ST. L.J. 507, 524 (2002) (noting that trigger matching funds depend on expenditures being fully disclosed and disclosure being strictly enforced).

17. See Herbert M. Kritzer, Law is the Mere Continuation of Politics by Different Means: American Judicial Selection in the Twenty-First Century, 56 DePaul. L. Rev. 423, 431 (2007) (indicating that " $[t]$ he United States is almost unique in its use of elections in the judicial selection and retention process").

18. Cass R. Sunstein, Political Equality and Unintended Consequences, 94 Colum. L. Rev. 1390, 1397 (1994). 
I.

\section{THE CONTRIBUTIONS VS. EXPENDITURES CONUNDRUM}

\section{A. Buckley and the Birth of a Distinction}

A generation ago, in Buckley $v$. Valeo, ${ }^{19}$ the Supreme Court, in analyzing the Federal Election Campaign Act, ${ }^{20}$ issued a fractured per curiam ruling that remains the foundational, if much-criticized, landmark of campaign finance law to this day. ${ }^{21}$ As Professor Hasen notes, the Court "decided a number of important legal issues . . including upholding the challenged disclosure provisions, upholding the constitutionality of the voluntary public financing system for presidential elections, and striking down the process for choosing members of the [Federal Election Commission]."22 However, the most enduring, or at least enduringly controversial, aspect of the decision is the Court's distinction between campaign contributions and campaign expenditures.

In Buckley, the Supreme Court famously-or infamously-upheld campaign contribution limits as a means of preventing corruption and the appearance of corruption ${ }^{23}$ and simultaneously struck down limits on expenditures by individuals and groups as violating the First Amendment. ${ }^{24}$ While the Court's ruling has been criticized to the point where it has been made clear that a majority of the Supreme Court would overrule it on one ground or another, ${ }^{25}$ Buckley remains the starting point of any campaign finance analysis.

19. 424 U.S. 1 (1976).

20. See Federal Election Campaign Act Amendments of 1974, Pub. L. No. 93$443, \S \S 101,202,310,403,88$ Stat. 1263, 1263-68, 1275-76, 1280, 1291 (1974) (codified as amended at 2 U.S.C. $\$ \S 431-56(2006)$ ), invalidated in part by Buckley v. Valeo, 424 U.S. 1 (1976).

21. Buckley, 424 U.S. at 1.

22. Richard L. Hasen, The Nine Lives of Buckley v. Valeo, in First AmEndment Stories (Richard W. Garnett \& Andrew Koppelman eds., forthcoming 2011) (manuscript at 19), available at http://ssrn.com/abstract $=1593253$.

23. Buckley, 424 U.S. at $29,84$.

24. Id. at $16-17,19$.

25. See, e.g., Richard Briffault, Nixon v. Shrink Missouri Government PAC: The Beginning of the End of the Buckley Era?, 85 MINN. L. REv. 1729, 1757 (2001) (noting "the rejection of critical elements of Buckley by a majority of the justices" at the time, and that "Justices Kennedy, Scalia, Thomas, and Stevens . . expressly called either for overruling of Buckley entirely or for overruling key elements of the decision" while Justices Breyer and Ginsburg "expressed the hope that Buckley could be salvaged through significant reinterpretation, including the modification of . . . the contribution/expenditure distinction"). Indeed, writing as of 2001, Professor Briffault noted that "[o]nly Justices Souter, O'Connor and Chief Justice Rehnquist raised no questions about the continuing states of Buckley," an observation that is 
In addition to establishing the contribution-expenditure dichotomy, the Court's distinction was driven by the Court's exclusive focus on the anti-corruption interest.

The Court's emphasis on the anti-corruption rationale resulted from the specific concern that "large contributions are given to secure a political quid pro quo from current and potential officeholders." 26 That focus on quid pro quos inevitably led to the conclusion that independent expenditures in support of a candidate's campaign failed to pose the same risk of corruption. Such expenditures by definition excluded coordination, much less a quid pro quo. Arguably, however, the Court's mistake was not the focus on corruption. Instead, the Court's error was its singular focus on quid pro quo exchanges as the only basis for that corruption. With respect to contributions, the Court specifically found that the interest "in alleviating the corrupting influence of large contributions" justified limiting the size of contributions and upholding FECA's disclosure provisions. ${ }^{27}$

Effectively, the Court found that "a limit on the amount of campaign contributions only marginally restricted a contributor's ability to send a message of support for a candidate" 28 whereas "campaign expenditures were core political speech" thus necessitating "exacting scrutiny." 29 Thirty-five years after the Court's decision, the contribution-expenditure distinction is well-worn black-letter shorthand. Yet, rather than merely taking the bar on expenditure limitations at face value, it is worth noting that the Court, of course, was not considering the concepts in the abstract. Rather, it was considering the expenditure limitations in FECA itself. In that regard, even in 1970s dollars, FECA's specific limits were extraordinarily stringent. ${ }^{30}$

particularly telling given that (a) that doesn't necessarily mean they didn't have such questions and (b) that none of those three remains on the Court today. Id.

26. Buckley, 424 U.S. at 26.

27. Id. at 55 .

28. Hasen, supra note 22, at 19-20.

29. Id.

30. FECA carefully regulated political expenditures with a series of caps, all of which the Court ultimately struck down. Campaigns were subject to stringent expenditure limits. Presidential campaigns were capped at $\$ 10$ million for the primaries, and $\$ 20$ million for the general election. Senate campaigns were limited to 8 cents a voter for the primaries, and 12 cents a voter for the general election. House campaigns were limited to $\$ 70,000$ for the primaries and $\$ 70,000$ for the general elections. These spending limits were indexed annually for inflation. Finally, the independent spending of individuals was limited to $\$ 1,000$ in support of a federal candidate. For example, Voter Jones could take out a newspaper ad supporting Candidate Smith if Jones' costs were $\$ 1000$ or less. Candidates were permitted to 
In recent years, even the most ardent proponents of campaign finance regulation have acknowledged that "FECA's spending limits were set at an unreasonably low level" and that, accordingly, the "Court was correct to note that the $\$ 1,000$ ceiling on independent expenditures was a de facto ban on political participation, and FEC's $\$ 70,000$ limit for House races was also unreasonably low." 31 Whether substantially higher limits would have generated a different result is now a matter of pure speculation. ${ }^{32}$ Moreover, whatever the result in Buckley might have been with higher limits, the Court's decision in Citizens United v. Federal Elections Commis$\operatorname{sion}^{33}$ is just the latest indication that the current Supreme Court would not be solicitous of spending limits-at least not in legislative and executive races.

\section{B. The Unintended Consequences of Buckley}

Buckley's singular focus on the anti-corruption rationale manifests in several aspects: (1) framing the campaign spending debate; (2) restraining both campaign regulation proponents and opponents; and, most importantly, (3) shaping political campaigning itself. Scholars who are critical of Buckley argue that "expenditures on behalf of a candidate can create some of the dangers of contributions. Candidates often know who spends money on their behalf and for this reason, an expenditure may in some contexts give rise to the same reality and appearance of corruption." 34 Assuming ar-

spend up to $\$ 50,000$ of their own money on a presidential campaign, $\$ 35,000$ on a Senate campaign, and $\$ 25,000$ on a House campaign. See NEUBorne, supra note 14 , at 9 .

31. Id. at 16.

32. In Buckley itself, Justice White would have sustained the spending limits as "essential to prevent transparent and widespread evasion of the contribution limits" while Justice Marshall would have sustained the limits on personal expenditures in service of the "reality and appearance of equal access to the political arena." Buckley, 424 U.S. at 262 (White, J., concurring in part and dissenting in part); id. at 287 (Marshall, J., concurring in part and dissenting in part). For a detailed and fascinating discussion of the individual justices' positions in Buckley, both in the opinion itself and from the pertinent historical papers, see Hasen, supra note 22.

33. Citizens United v. FEC, 130 S. Ct. 876 (2010). With respect to predictions, an insightful student note indicates that "[o]ver the past twenty years, the Court's fractured and anomalous jurisprudence has led commentators to repeatedly conclude that Buckley's fall was imminent" but "[ $\mathrm{t}]$ he present Court seems certain not to overrule Buckley in favor of a deferential approach to regulation." J. Robert Abraham, Note, Saving Buckley: Creating a Stable Campaign Finance Framework, 110 Colum. L. REv. 1078, 1092 (2010) (internal footnotes omitted).

34. Sunstein, supra note 18, at 1395 (citing examples in DAN CLAWSON ET AL., Money Talks: Corporate PACs and Political Influence $75-79$ (1992)). 
guendo that the Court's failure to recognize this dynamic was in error, it occurred against a political landscape bearing little relation to the expensive, orchestrated independent expenditure campaigns of the Swift Boat and MoveOn era, ${ }^{35}$ much less the And For the Sake of the Kids judicial elections era. ${ }^{36}$

As Professor Neuborne notes, this "is where the Buckley Court suffers most from having been without a factual record. Enormous independent expenditures were not part of the fictional record the Court considered, mostly because they were not yet part of America's political process." 37 Because such expenditures had become a part of America's presidential and congressional political process since a generation ago, their continued absence from judicial elections until only very recently was even more pronounced. ${ }^{38}$ Conversely, in the era of costly campaigns, conducted mostly via television advertisements, little doubt exists that elected "officials can be influenced by who spends money on their behalf, just as they can be influenced by who directly contributes money to them. The perception of corruption might be generated by large expenditures for a candidate, just as it can be caused by large contributions." 39

From a realpolitik perspective, the contributions-expenditures distinction is a lesson in unintended consequences. On the bright side, those unintended consequences have become a rich source of colorful metaphor. Professors Karlan and Issacharoff note that the "result is an unceasing preoccupation with fundraising. The effect is much like giving a starving man unlimited trips to the buffet table but only a thimble-sized spoon with which to eat: chances are great that the constricted means to satisfy his appetite will create a singular obsession with consumption." 40 Similarly, Josh Rosenkranz writes that the unlimited demand for money resulting from a lack of limits on expenditures, combined with the restricted supply resulting from contribution limits, turns "decent, honest politicians" into "junkies . . . caught in the political equivalent of an arms race in which neither side feels safe to disarm unilaterally because each

35. See infra notes $67,68,75$.

36. See infra note 159 .

37. NeUBORne, supra note 14 , at 16 .

38. See infra Part II.B.

39. Erwin Chemerinsky, Preserving an Independent Judiciary: The Need for Contribution and Expenditure Limits in Judicial Elections, 74 CHI.-KeNT L. REv. 133, 143-44 (1998).

40. Samuel Issacharoff \& Pamela S. Karlan, The Hydraulics of Campaign Finance Reform, 77 TEx. L. REv. 1705, 1711 (1999). 
candidate lives in mortal fear of being buried by the other's spending." 41

Buckley's construction of the contribution-expenditure distinction thus manifests a paradoxical conundrum: the FECA system that was designed to reduce the influence of money in politics, warped by Buckley, has instead exponentially increased the import of chasing every last dollar. ${ }^{42}$ Furthermore, since an increasing number of contribution sources were inevitably required, the marginal sources of the contributions were inevitably further and further afield from a candidate's core, philosophically aligned base. Consequently, at least in some instances, such as when a candidate seeking contributions from groups and individuals with a particular interest about which the candidate himself or herself would otherwise be neutral or even apathetic, the dynamic almost assuredly results in the very type of express or implied quid pro quo exchanges that Buckley deemed most pernicious.

The exclusivity of the anti-corruption interest defines the rhetorical push and pull of the campaign finance regulatory debate as well. Professors Issacharoff and Karlan skeptically note that "calls for reform all stem from the assertion that money corrupts the electoral process." 43 They note that this characterization dominates discussions of reform despite the indeterminate nature of what is really meant by "corruption." 44 Professors Issacharoff and Karlan acknowledge that while this may be "primarily as a response to Buckley ... it may well be that even in the absence of the Buckley imperative, arguments for campaign finance reform would use images of corruption because of their rhetorical power." 45

Whether sourced in its "rhetorical power" or not, the focus on anti-corruption leads to two concrete analytical problems. The first problem, as Professors Persily and Lammie have noted, is the "trap that has snared the current Court and those who have analyzed the campaign finance decisions: namely, the alternating tendencies of the word 'corruption' to mean everything and nothing." 46 The sec-

41. E. Joshua Rosenkranz, Faulty Assumptions in "Faulty Assumptions": A Response to Professor Smith's Critiques of Campaign Finance Reform, 30 CoNN. L. REv. 867, 889 (1998).

42. See infra Part II.B.

43. Issaacharoff \& Karlan, supra note 40 , at $1707-08$.

44. Id. at 1708 .

45. $I d$. at 1719 .

46. Nathaniel Persily \& Kelli Lammie, Perceptions of Corruption and Campaign Finance: When Public Opinion Determines Constitutional Law 119, 122 (U. Penn. Inst. for Law \& Econ. Research Paper 04-22, U. Penn. Law School, Public Law Working Paper 53, 2004), available at http://ssrn.com/abstract $=595721$. 
ond problem is that "the unique position of "appearance of corruption'. . . has more to do with the difficulties of proving actual corruption ... than the importance of the state interest in combating such negative perceptions." 47

Were the Supreme Court to exorcise the "appearance of corruption" state interest from the campaign finance jurisprudence, few campaign finance regulations would pass constitutional scrutiny. Antireformists might greet this development with cheer, but without the fallback on appearances and perceptions, defenders of campaign finance reforms would be left with the difficult job of proving that (1) campaign contributions have actually corrupted representatives, and (2) antibribery laws are insufficient to combat actual corruption. The existence of the fallback state interest of preventing appearances allows judges to say that, while they think examples of actual corruption justify the given reform, the existence of widespread appearances of corruption removes all doubt. ${ }^{48}$

Professors Persily and Kammie's points are valid across the spectrum of democracy. Yet, as Parts II and III of this Article explain in more detail, proving corruption is more of a hurdle in the judiciary than in any other political arena. Furthermore, the judiciary is precisely where even the most marginal and subconscious influence of financial support can jeopardize both systemic integrity and individual rights.

In addition to the dynamic of the "unlimited trips to the buffet" with the "thimble-sized spoon" 49 and the other unintended consequences described above, critics of campaign finance restrictions point to another significant worry: if "reform advocates had their way, they would discover what the Corps of Engineers learned over the years in trying to redirect the Mississippi. Money, like water, will seek its own level" and, consequently, "[t] he price of containment may be uncontrolled flood damage elsewhere." 50

\section{The Rising Tide of Independent Expenditures}

Whether the money-like-water dynamic is categorically unavoidable or merely a function of the Buckley jurisprudence is a debate beyond the scope of this article. One product of the "uncontrolled flood damage," however, is very much on point-the

47. Id. at 133 .

48. Id. at 134 .

49. Issacharoff \& Karlan, supra note 40 , at 1711.

50. Id. at 1713 . 
extent to which the real-world result of Buckley's sharp line between regulable contributions and non-regulable expenditures is the rise of contemporary big-dollar independent expenditure campaigns.

Writing nearly 30 years ago, Judge Skelly Wright ${ }^{51}$ lamented even then how, "in recent years, [Political Action Committees (PACs) ]-especially those connected with corporations and trade associations-have grown explosively in numbers and influence"52 and, more tellingly, that FECA, along with Buckley "facilitated their formation and operation." 53 PAC contributions to candidates and independent expenditures are apples and oranges. ${ }^{54}$ Yet, Judge Wright's description included, as foreshadowing, a reflection that "PAC's, especially those with ideological or single-issue orientations, spend large sums of money on highly effective campaigns against 'hit listed' activities for or against particular candidates." 55 In 1980 alone, PACs had "devoted more than $\$ 14$ million" to independent expenditure campaigns. ${ }^{56}$ In a comment that would prove only more prescient over time, Judge Wright stated simply, "Because Buckley $v$. Valeo constitutionally invalidated ceilings on "independent' expenditures, this type of spending may theoretically be unlimited." 57 Judge Wright found it telling that the biggest injections of wealth "into the political bloodstream" came from "the more highly regulated industries, such as oil, transportation, utilities, drugs, health care, and government contracting." 58 Looking at Judge Wright's list three decades later-especially in the context of

51. Judge Wright was on the panel of the D.C. Circuit Court of Appeals that was reversed by the Supreme Court in Buckley. See Buckley v. Valeo, 519 F.2d 821, 831 (D.C. Cir. 1975), aff'd in part, rev'd in part, 424 U.S. 1 (1976).

52. J. Skelly Wright, Money and the Pollution of Politics: Is the First Amendment an Obstacle to Political Equality?, 82 Colum. L. REv. 609, 614-15 (1982) (noting that between 1974 and 1982, number of corporate PACs went from 89 to 1327 and that "[b]etween 1976 and 1980 PAC's more than doubled the amounts of money they poured into House and Senate campaigns- $\$ 22.6$ million in $1976, \$ 35.2$ million in 1978 , and $\$ 55.3$ million in $1980 ")$.

53. Id. at 614 .

54. For a clear and insightful overview of the tax and campaign finance distinctions between PACs, $527 \mathrm{~s}$, and the consequences of being defined, or not defined, as a "political committee" under the law, see Paul S. Ryan, 527s in 2008: The Past, Present, and Future of 527 Organization Political Activity Regulation, 45 Harv. J. ON L.EGIS. 471 (2008).

55. Wright, supra note 52, at 616 .

56. $I d$.

57. Id.

58. Id. 
judicial elections-one is hard pressed not to think of the French epigram, plus ça change, plus c'est la même chose. ${ }^{59}$

Largely because the rhetoric concerning campaign finance involves the intersection of the First Amendment and politics, it is marked as much by tropes, anecdotes, and shoehorning as by meritorious dialectic. Professors Issacharoff and Karlan treat reformers' less-than-credible overreliance on corruption arguments with appropriate skepticism. ${ }^{60}$ Similarly, the most insistent opponents of campaign regulation overemphasize homespun stories that-were they the rule rather than the rarest of exceptions-would indicate that the real aim of campaign regulation is neither to prevent corruption nor to reduce political inequality. Instead, campaign regulation opponents attempt to create the impression that campaign regulations seek to prevent Mom \& Pop from ever expressing a political viewpoint. ${ }^{61}$ Indisputably, true stories of the unwittingly ensnared exist in campaign finance just as in other regulatory schemes. Regarding independent expenditures in political campaigns, however, the numbers tell a very different story; the vanguard of the genre is not Mom and Pop-at least not unless Mom and Pop spend tens of millions through a "527."

59. "The more things change, the more they stay the same."

60. See Issacharoff \& Karlan, supra note 40, at 1708 (addressing paradoxes inherent within reformers' assertions that the election process is corrupted by the influx of money).

61. Former FEC Commissioner Bradley A. Smith employs this type of advocacy particularly effectively. Below is a typical example of this technique, as well as one of Smith's favorite anecdotes:

In the autumn of 2000 , Harvey Bass, the owner of Harvey Bass Furniture and Appliance in the west Texas town of Muleshoe, painted "Save our Nation: vote Democrat; Al Gore for President" on the side of a leftover refrigerator shipping box. Bass left the homemade sign on the porch of his business on State Highway 214 , to be seen by passersby. Soon another local resident, Bill Liles, "got tired of looking at it, especially the 'Save our Nation' part." Liles and a friend, one Mark Morton, decided to make a sign supporting Gore's rival, Texas Governor George W. Bush. The two decided that their sign "should be bigger and better." They obtained a large plywood board, hired a professional sign painter, and mounted the finished product on the side of a cotton trailer obtained from another local resident, Don Bryant. They parked the trailer, with its sign, across the street from Mr. Bass's store. "As word spread the sign became a topic of conversation at local gathering places. Mostly the Spudnut Shop on Main Street and the Dinner Bell Café on Highway 84. People started coming by and donating to help pay for the cost of the sign."

This spontaneous burst of political activity ended when another Muleshoe resident, Don Dyer, filed a complaint with the Federal Election Commission against Liles, Morton, Bryant, and one of their "contributors."

Bradley A. Smith, Campaign Finance Reform: Searching for Corruption in All the Wrong Places, 2003 Cato Sup. Ct. Rev. 187 (2003). 
Named for the section of the Internal Revenue Code under which they are organized, 527s frequently make independent expenditures to support or oppose political candidates. ${ }^{62}$ "In the world of campaign finance, 2004 was without a doubt the year of the 527 organization." 63 Estimates of spending by $527 \mathrm{~s}$ in the groundbreaking 2004 federal election "amounted to at least $\$ 405$ million, accounting for more than one-tenth of total federal election spending and perhaps twenty to twenty-five percent of spending in the presidential campaign." 64 The year 2004 also produced what remains the best-known 527 organization ever: the Swift Boat Veterans for Truth, ${ }^{65}$ whose campaign against John Kerry generated what pollsters described as a "staggering" awareness among nearly three out of four voters in $2004 .{ }^{66}$ When voters in that election were asked which 527 group had the most impact on the 2004 race, "almost as many voters cited Swift Boat Veterans as cited all the other 527's combined." 67

Even the strategic deployment of 527s, through which Democratic-leaning 527s outspent their Republican-leaning adversaries by nearly a $3: 1$ spending margin, ${ }^{68}$ was a lesson in unintended consequences: "The Democrats built these new shadow-party advocacy groups to attack the president early in the campaign season and build voter-turnout machines. Then they watched Bush partisans

62. 26 U.S.C. $\$ 527$ (2006).

63. Richard Briffault, The 527 Problem ... and the Buckley Problem, 73 Geo. WASH. L. REV. 949, 949 (2005).

64. Id. (citing Stephen R. Weissman \& Ruth Hassan, BCRA and the 527 Groups, in The Election After Reform: Money, Polttics, and the Bipartisan Campaign ReForm Act 79 (Michael Malbin ed., 2006)).

65. See John J. Miller, What the Swifties Wrought, Nat'L Rev., Nov. 29, 2004, at 18 (asserting that the Swift Boat Campaign "will go down in history for its stunning effectiveness"); Briffault, supra note 63 .

66. Public Release of National Survey Results, Fabrizio, McLaughlin \& Associates, 527's Matter and Swift Boat Vets Top the Heap - Best Known, Most Impact and Highest Ad Recall (Nov. 4, 2004), available at http://www.fabmac.com/FMA2004-11-04-527-Effects.pdf.

67. Id. The best known of the 527s supporting Senator Kerry was MoveOn.org. See id. MoveOn.org was supported with millions of dollars from sources including George Soros and Peter Lewis. For a chart detailing MoveOn's top contributors during the 2004 cycle MoveOn.org: Top Contributors, 2004 Cycle, Center for ResPonsive Politics (2010), http://www.opensecrets.org/527s/ $527 \mathrm{~cm}$ tedetail_contribs.php?ein $=2002340658 \mathrm{cycle}=2004$.

68. Editorial, The Soft Money Boomerang, N.Y. Times, Dec. 29, 2004, at A20, available at http://query.nytimes.com/gst/fullpage.html?res=9B03E2D71639F93A A15751C1A9629C8B63. 
adapt the same financing device to float the campaign's most notorious and devastating attack ads, the Swift Boat assault . . .."69

At least in terms of public expression-with private and strategic thinking being inherently harder to measure-527s were broadly scorned, even by their biggest beneficiaries. Former President George W. Bush, for example, stated, "I don't think we ought to have 527's [sic] . . . I I can't be more plain about it and I wish-I hope my opponents join me in saying-condemning these activities of 527's [sic]. I think they are bad for the system."70 It is not often that a question of campaign finance generates agreement so broad that it encompasses President Bush and Wisconsin Senator Russell Feingold. Senator Feingold argues that 527s allow "wealthy individuals to drown out the voices of average citizens."71 Senator Feingold's critique was echoed, most notably, by his frequent collaborator in regulating campaign finance, Senator John McCain. Senator McCain asserted that $527 \mathrm{~s}$ must be limited so that "political power in this country does not lie solely in the hands of big corporations, labor unions, and the wealthiest of the wealthy."72

The ideological diversity represented by these three political figures would, at least superficially, seem to bode well for those favoring limits on independent expenditures. However, on closer examination, one realizes quickly that not one of these arguments references "corruption." Moreover, Senators Feingold and McCain expressly invoke the prohibited leveling rationale, while President Bush's "bad for the system" remark seems to strongly indicate a non-corruption concern. Consequently, even if modest registration requirements, disclosure provisions, and other regulations are imposed on 527 organizations, fundamental reforms aimed at limiting their reach run headlong in the Buckley bulwark, which makes corruption the sole justification for regulation of campaign financing. A circular relationship thus connects the rhetoric with the Buckleybased reality. First, this reality requires that those who want to limit

69. $I d$.

70. Elizabeth Bumiller \& Kate Zernike, President Urges Outside Groups to Halt All Ads, N.Y. TIMEs, Aug. 24, 2004, at A1, available at http://www.nytimes.com/2004/ 08/24/politics/campaign/24swift.html.

71. Briffault, supra note 63, at 995 (citations omitted) (quoting Hearing to Examine and Discuss S. 271, a Bill Which Reforms the Regulatory and Reporting Structure of Organizations Registered Under Section 527 of the Internal Revenue Code, 109th Cong. (2005) (statement of Sen. Russell Feingold)).

72. Id. (emphasis added) (citations omitted) (quoting Hearing to Examine and Discuss S. 271, a Bill Which Reforms the Regulatory and Reporting Structure of Organizations Registered Under Section 527 of the Internal Revenue Code, 109th Cong. (2005) (statement of Sen. John McCain)). 
expenditures must emphasize an anti-corruption nexus that is only tangentially connected to their real democratic concerns, and must focus on limiting contributions rather than expenditures. Second, those who oppose or are at least less sanguine about expenditure limitations can decry massive special interest capture without any risk that the money will stop flowing.

The combination of the Buckley bulwark against regulation of $527 \mathrm{~s}$ and the high-profile success of the Swift Boat campaign in the 2004 presidential election ${ }^{73}$ rendered imitation and expansion of the independent expenditure model virtually inevitable, even at the state level. But where did the money come from? In some respects, the role of 527s in the 2004 election dovetails with the hydraulics theory. ${ }^{74}$ As Professor Briffault notes, "many observers contend[ed] that contributions to and expenditures by $527 \mathrm{~s}$ were little more than evasions of the recently enacted Bipartisan Campaign Reform Act of 2002 ("BCRA") and re-creations of the soft money problem that BCRA was supposed to have eliminated." 75 However, in analyzing a study conducted by Steve Weissman and Ruth Hassan, Professor Briffault describes a dynamic less marked by hydraulics. Instead, the ability of singular parties contributes to the dynamic; Briffault describes these parties as "megadonors" who play, in essence, a mega-role:

[I]t was not simply a matter of old money finding new venues. The real source of the explosion of 527 activity was contributions from individuals, especially very large contributions by individuals. Most of this money had not been in the preBCRA soft money system at all, but instead entered the electoral process in 2004 for the first time. A total of 1882 individuals made contributions to $527 \mathrm{~s}$ of $\$ 5000$ or more apiece, and they gave an aggregate of $\$ 256$ million. Although the median donation was only $\$ 12,000$, the mean contribution was $\$ 135,805-$ twenty-seven times the statutory ceiling on individual donations to FECA political committees-because of the dominant role of a small number of extremely large donors. Indeed, there were twenty-four individuals or couples who each gave $\$ 2$ million or more. This handful of megadonors collectively gave a staggering $\$ 142.5$ million. To put this number in context, it is

73. Richard Briffault notes that "the activities of the pro-Republican 527s, particularly the Swift Boat Veterans, demonstrate that $527 \mathrm{~s}$ can give powerful support to a candidate while still operating independently of the candidate's campaign." Id. at 969 .

74. See supra note 40 and accompanying text.

75. Briffault, supra note 63 , at 950 . 
roughly equal to the aggregate of $\$ 149.2$ million in public funds provided to the two presidential nominees for the general election campaign. The $\$ 142.5$ million in 527 funds, however, came from just two dozen megadonors, while the $\$ 149.2$ million in public funds came from the entire American public. ${ }^{76}$

A similar "megadonor" dynamic is increasingly coming to the fore in state judicial elections. While unregulated political activity by 527 organizations has not affected all or even most state and local governments, ${ }^{77}$ isolated state contests have turned into flashpoints for large independent expenditures. And as Part II explains, as a proportional matter, "megadonors" play an even more outsized role in judicial contests than the role Professor Briffault describes above in the presidential context.

II.

\section{CAMPAIGN CASH AND THE NEW POLITICS OF JUDICIAL ELECTIONS}

Judicial elections are particularly susceptible to being decided by large contributions or expenditures by particular individuals or organizations for multiple reasons. Judicial elections are low-salience affairs, making contributions from the so-called "average" voter hard to find..$^{78}$ At the same time, for the "exceptional" voter who has a high-value lawsuit pending or routinely asks the state courts to vindicate their economic interests, the concentrated benefit could scarcely be higher. Thus, for the "exceptional" interest, who is a major and/or repeat player in the courts, spending even millions of dollars on a candidate for the state supreme court quickly yields a favorable cost-benefit analysis. On the other hand, for the vast majority of citizens-with hugely important but highly diffuse interests in the caliber and fairness of their state courtsequivalent "major" spending is irrational. Not only is it a financial impossibility, but the cost-benefit analysis of even minimal spending on a judicial campaign is abysmal. There is not currently, nor is there likely to be, a "small-donor revolution" in judicial elections any time soon. Three million dollars in West Virginia or Alabama or Wisconsin-or even in more expensive markets like Washington, Illinois, Michigan or Ohio-can buy a whole lot of misinformation.

76. Briffault, supra note 63, at 964 (emphasis added) (internal citations omitted).

77. Ryan, supra note 54 , at 505 .

78. See, e.g., infra Part II.D (showing clear examples of "exceptional" spenders). 
And as campaign spending has skyrocketed overall in the past few decades, judicial campaign spending, specifically, has gone into orbit, at least by historical standards.

\section{A. Everything's Bigger in Texas}

In the modern era, the specter of massive judicial campaign support from parties and lawyers with specific interests before the court is traceable to the 1982 Texas Democratic Primary. In that primary, a controversial repeat litigant, described as a "South Texas rancher and oil man," contributed $\$ 200,000$ to an unsuccessful candidate for the Texas Supreme Court-a sum that represented more than $90 \%$ of the candidate's campaign support. ${ }^{79}$

Three years later, Texas once again pioneered today's brave new world of judicial elections in a highly charged case between energy giants Pennzoil and Texaco. Two days after filing its answer, Pennzoil contributed $\$ 10,000$ to the pre-trial judge through one of its lawyers ${ }^{80}$ as well as another $\$ 10,000$ to the judge in charge of assigning trial judges. ${ }^{81}$

Texaco's attorneys, who demanded a new trial on the basis of the $\$ 10,000$ contribution by their adversary to the trial judge, then responded by contributing “ $\$ 72,700$ to seven Texas Supreme Court justices who were expected to make the final ruling in the case." 82 The seven justices to whom Texaco contributed included three justices not even up for re-election. ${ }^{83}$ Ultimately, Pennzoil and its lawyers contributed $\$ 315,000$ to judges involved in the litigation, outspending Texaco's $\$ 72,700$ by a factor of four. ${ }^{84}$ "Perhaps coincidentally, the courts ultimately ruled in favor of the highest bidder. Although it is clearly plausible that Pennzoil prevailed solely on the merits of its arguments, the attack on judicial independence and integrity that stemmed from the contributions tainted the outcome." 85

79. See Anthony Champagne, The Selection and Retention of Judges in Texas, 40 Sw. L.J. (Special Issue) 53, 84 (1986).

80. See Texaco, Inc. v. Pennzoil Co., 729 S.W.2d 768, 842 (Tex. App. 1987).

81. See Mark Andrew Grannis, Note, Safeguarding the Litigant's Constitutional Right to a Fair and Impartial Forum: A Due Process Approach to Improprieties Arising From Judicial Campaign Contributions from Lawyers, 86 MicH. L. Rev. 382, 404 (1987).

82. Jason Miles Levien \& Stacie L. Fatka, Cleaning Up Judicial Elections: Examining the First Amendment Limitations on Judicial Campaign Regulation, 2 MicH. L. \& POL'y REV. 71 (1997).

83. See Kathryn Abrams, Some Realism About Electoralism: Rethinking Judicial Campaign Finance, 72 S. CAL. L. REv. 505, 517 (1999).

84. Levien \& Fatka, supra note 82, at 71.

85. Id. at 71-72. 
While the facts and figures in Pennzoil were extreme, they also reflected a near-standard operating procedure within the state's courts for decades. In a study of the Texas State Bar regarding the state's courts, $79 \%$ of attorneys surveyed indicated their belief that campaign contributions significantly influence a judge's decision. ${ }^{86}$

\section{B. 2000-2009: Cash in the Courtroom Goes National}

The national trend of big-money judicial campaigns began in the late 1990s. In the 1999-2000 election cycle, state supreme court candidates raised nearly $\$ 46$ million-a $62 \%$ increase over $1998 .{ }^{87}$ Alabama's 2000 election for a seat on the state high court set a short-lived judicial-race record of $\$ 4.8$ million. ${ }^{88}$ That same year, "national and business media were reporting on how the business sector was fighting to shift the balance on state courts back from what many considered a pro-plaintiff bias." 89 For example, in 2000 , the U.S. Chamber of Commerce and its state chapters announced that they were going to prioritize the funding of high court campaigns. They were not kidding. Commenting on the $62 \%$ jump in overall spending from 1998 to 2000, Roy Schotland wrote: "That increase was no 'sport,' but a new peak in a clear, dramatic trend whether viewed in terms of total dollars, or dollars-per-seat, or percentages." 90 In the decade since the 2000 watershed, big money has become a prerequisite for a viable high-court campaign, and for many lower state courts as well. The speed of the geographically dispersed transformation is remarkable and measurable both empirically and anecdotally.

Perhaps the best way to understand the rise in judicial spending starting in 2000 is to consider the following graph. This graph illustrates, at two-year intervals, the percentage of states with highcourt elections in which the campaigns included television advertising, which is the biggest driver in campaign costs from 2000-06:

86. See Alexander Wohl, Justice for Rent, Am. ProsPecr, Nov. 30, 2002, available at http://www.prospect.org/cs/articles?article=justice_for_rent.

87. See Sample et al., supra note 11 , at 5.

88. See Deborah Goldberg et al., The New Politics of Judicial Elections 2004: How Special Interest Pressure on Our Courts Has Reached a "Tipping Point"- And How to Keep Our Courts Fair and Impartial 32 (2005), available at http://brennan.3cdn.net/dd00e9b682e3ca2fl7_xdm6io68k.pdf.

89. See SAMple et Al., supra note 11 , at 39 .

90. Roy A. Schotland, Financing Judicial Elections, 2000: Change and Challenge, 2001 L. Rev. Mich. St. U.-Detroit C.L. 849, 862. 
Percentage of States With Contested Supreme Court Elections

Featuring TV Advertising, 2000-2008 ${ }^{91}$

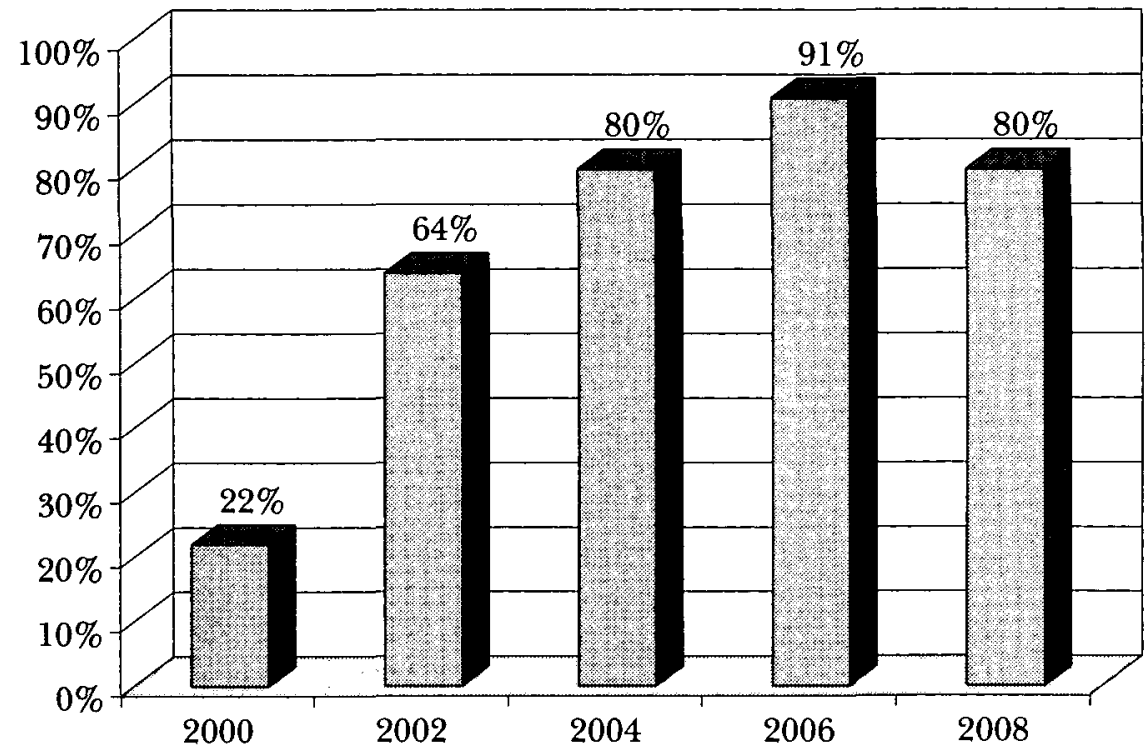

The chart verifies the highly compressed chronology of the transformation in judicial campaigns. In just eight years, television advertising in state high-court races went from a one-in-five exception to a prerequisite in all but the least seriously contested races. Moreover, where significant television advertising exists, massive spending-in the form of either contributions or outside expenditures, or both-is guaranteed to exist as well.

Across the country, judicial campaign spending records have been broken repeatedly throughout the past decade. Forty percent of the states holding contested supreme court elections (nine of twenty-two) broke aggregate candidate fundraising records in the 2003-2004 election cycle. ${ }^{92}$ In the 2005-2006 cycle, "half of the states that held entirely privately-financed, contested supreme court elections (five of ten) broke state fundraising records." 93 In 2007-2008, state supreme court candidates raised \$45.6 million;

91. See SAMPLE ET AL., supra note 11 , at 24 . Counting a bitterly contested and expensive 2007 Wisconsin campaign, the 2007-08 cycle featured sixteen states with contested supreme court races, with television ads running in fourteen of them (more than eighty-five percent). Id.

92. GoldBerg ET AL., supra note 88 , at 13.

93. James Sample et al., Justice at Stake Campaign, The New Politics of Judicial Elections 200615 (2006), available at http://www.brennancenter.org/ content/resource/the_new_politics_of_judicial_elections_2006/. 
this sum was seven times the 1989-90 total. ${ }^{94}$ The figure marked the third time in the last five two-year cycles that, nationally, state supreme court candidates raised more than $\$ 45$ million. ${ }^{95}$ Alabama offers a good illustration. In the 2005-2006 election cycle alone, state supreme court candidates in Alabama raised $\$ 13.4$ million, surpassing the previous state record by more than $\$ 1$ million..$^{96}$ The three candidates for Chief Justice raised a combined $\$ 8.2$ million, making it the most expensive judicial race in state history and the second-most expensive judicial campaign in American history. ${ }^{97}$

During the decade as a whole, "[twenty] of the [twenty-two] states that elect [s]upreme [c]ourt judges set spending records; only Texas and North Dakota had their highest-spending elections in the 1990s." 98 In the 1990s, only three states-Alabama, Pennsylvania, and Texas-had judicial campaigns in which over \$1 million was raised. From 2000 to 2009 , sixty-six campaigns raised $\$ 1$ million or more in twelve states-over half of the twenty-two states that hold judicial elections for their highest courts. ${ }^{99}$ The numbers are even more dramatic when viewed from a broader perspective. From "2000-09, Supreme Court candidates raised $\$ 206.9$ million nationally, more than double the $\$ 83.3$ million raised from 1990-1999." 100 That increase of more than $250 \%$ is ten times the increase in the consumer price index during the same period. ${ }^{101}$

The judicial candidate with the most funds in a race generally wins the election. In 2006, the candidate who raised the most money in state high court races won $68 \%$ of the time. ${ }^{102}$ In 2004, that figure was $85 \% .^{103}$ In itself, that proves little-the best candidates are also often the best at fundraising. The dynamic, however, exists in tandem with the fact that a substantial proportion of the contributions come from those with specific interests before the courts. For example, research by the National Institute on Money in

94. See SAMPLE ET AL., supra note 11 , at 8.

95. See id.

96. SAMPLE ET AL., supra note 93, at 15.

97. Id. Former Alabama State Bar President Mark White is a no-nonsense crusader to whom those committed to impartial courts owe substantial gratitude. In 2006, he noted that candidates for judicial office in Alabama spent more than twice Alabama's total annual spending on civil legal services for the poor. Editorial, Justice at any price, BIRMINGHAM News, July 23, 2008, at A8, available at 2008 WLNR 13791071.

98. SAMPLE ET AL., supra note 11 , at 8.

99. See id.

100. Id.

101. See id.

102. Id. at 31 .

103. See id. 
State Politics identified and disaggregated $84 \%$ of directly contributed funds in 2005-2006 state supreme court races. ${ }^{104}$ Business interests represented $44 \%$ of contributed funds, with lawyers making up the second-largest source at $21 \%$ of all contributed funds. ${ }^{105}$

\section{C. "There is no truth. There is only perception. " 06}

It is often remarked in varying forms that "without public confidence, the judicial branch could not function." 107 The flood of cash into judicial races is, predictably, jeopardizing that confidence. According to a 2004 public poll, more than $70 \%$ of Americans believe that judicial campaign contributions have at least some influence on judges' decisions in the courtroom. ${ }^{108}$

Staggeringly, nearly half of judges themselves agree with the public's perception. In a written survey of 2428 state lower, appellate, and supreme court judges, almost half $(46 \%)$ of the judges surveyed indicated a belief that campaign contributions influence judges' decisions. ${ }^{109}$ More than $70 \%$ of surveyed judges expressed concern regarding the fact that "[i]n some states, nearly half of all supreme court cases involve someone who has given money to one or more of the judges hearing the case." 110

Referring to the Avery case described below, ${ }^{111}$ Justice O'Connor, put the matter in provocative terms:

104. Id. at 18. This yeoman's work was made more challenging by lax campaign disclosure requirements, which made it impossible to identify and disaggregate $16 \%$ of the contributed funds nationwide, and a higher amount in particular states. Id. at fig. 11 .

105. Id. at 18 fig.11.

106. In the original French, "Il n'y a pas de Vrai! Il n'y a que des manières de voir. " Letter from Gustave Flaubert to M. Léon Hennique, (Feb. 2-3, 1880), in CORRESPONDANCE: ANNÉE 1880, available at http://flaubert.univ-rouen.fr/ correspondance/conard/outils/1880.htm.

107. In re Raab, 793 N.E.2d 1287, 1292 (N.Y. 2003).

108. Justice At Stake Campaign, March 2004 Survey Highlights: AmeriCans Speak Out On Judicial Elections (2004), http://faircourts.org/files/ZogbyPollFactSheet.pdf. These 2004 poll results are consistent with a 2001 nationwide poll, in which $76 \%$ of those surveyed stated their belief that campaign contributions influence judges' decisions. Greenberc Quinlan Rosner Research InC. \& Am. Viewpoint, Justice At Stake Frequency Questionnaire 4 (2001), http:// www.gqrr.com/articles/1617/1412_JAS_ntlsurvey.pdf.

109. Greenberc Quinlan Rosner Research Inc. \& Am. Viewpoint, Justice At Stake - State Judges Frequency Questionnaire 5 (2002), http://www.gqrr. com/articles/1617/1411_JAS_judges.pdf.

110. Id. at 9 .

111. See infra Part II.E. 
In 2004, there was a race for the Illinois Supreme Court, right here. It cost just over $\$ 9$ million for that race. As you might have guessed, the winner of that race got his biggest contributions from a company that had an appeal pending before the Illinois Supreme Court. You like that? ... Sounds a lot like the Caperton case, doesn't it? 112

A recent study of rulings by the Ohio Supreme Court by Adam Liptak and Janet Roberts added a layer of empirical support for these perceptions. ${ }^{113}$ The study found that Ohio justices routinely sat on cases after having received campaign contributions from the parties involved, and that they then voted in favor of those contributors $70 \%$ of the time. One justice voted in favor of his contributors $91 \%$ of the time. ${ }^{114}$

The perception that campaign contributions buy influence on the bench in pending or imminent cases is so strong that litigants and lawyers give even when their candidate cannot lose. A recent Los Angeles Times study found that Nevada judges running unopposed collected hundreds of thousands of campaign dollars from litigants and lawyers, frequently "within days of when a judge took action in the contributor's case . ..."115

\section{Super Spenders}

It is useful to recall Professor Briffault's analysis of 527 "megadonors" in the federal context. Briffault noted, most strikingly, that " $\$ 142.5$ million in 527 funds . . came from just two dozen megadonors" in the 2004 presidential election while, by comparison, " $\$ 149.2$ million in public funds came from the entire American public." 116 Briffault's eye-popping analysis is consistent with figures pointing to the outsized influence of a very few big spenders in state judicial elections. Super spenders fueled much of the cash boom in judicial elections in the past decade. These super spenders, who are stakeholders in litigation, can dominate election spending in either of two ways: (1) by writing huge campaign

112. Abdon M. Pallasch, O'Connor Urges Illinois to Select Judges by Merit, CHI. Sun-Times, May 20, 2010, at 7.

113. Adam Liptak \& Janet Roberts, Campaign Cash Mirrors a High Court's Rulings, N.Y. TIMEs, Oct. 1, 2006, at A1, available at http://www.nytimes.com/2006/ $10 / 01 /$ us $/ 01$ judges.html?_r=1\&scp=1\&sq=Campaign\%20Cash\%20Mirrors\%20a \%20High\%20Court's\%20Rulings\&st=cse.

114. See id.

115. Michael J. Goodman \& William C. Rempel, In Las Vegas, They're Playing with a Stacked Judicial Deck, L.A. Times, June 8, 2006, at A1, available at http:// www.corpwatch.org/article.php?id=13692.

116. Briffault, supra note 63 , at 964 . 
checks to candidates or (2) by going outside the system and spending millions on their own independent TV ads and other election communications, seeking to help or hurt a candidate on the ballot. ${ }^{117}$

"A review of ten states with the highest judicial campaign spending shows two separate worlds-a small coterie of organized super spenders who dominate election financing, and a large number of small contributors who simply cannot keep up." 118 As a consequence, a large number of justices in those states owe their elections to a few key benefactors. The gap is best shown by twentynine elections held from 2000-2009 in these ten states. ${ }^{119}$ In each of these elections, at least one of the candidates benefited from $\$ 1$ million or more in other people's money-either in direct contributions or through independent election spending by other groups. ${ }^{120}$

The top five super spenders from each of the twenty-nine elections-a total of 145 super spenders-spent an average of $\$ 473,679$ apiece. ${ }^{121}$ By contrast, the remaining 116,000 donors averaged $\$ 850 .{ }^{122}$ One finds relative super spenders even within the super spender category. Half of the money from those 145 spenders came from just twenty sources even while excluding money from self-financing candidates. ${ }^{123}$ In all, the 145 super spenders accounted for slightly over $40 \%$ of all campaign cash in the twenty-nine elections. ${ }^{24}$ Moreover, the disparity was widespread and not just the result of a few outlier contests. In twenty-two of twenty-nine elections, the top five spenders averaged more than $\$ 200,000$ apieceand in twelve elections, they averaged more than $\$ 500,000 .{ }^{125}$ In twenty-one of twenty-nine elections, a mere five spenders accounted

117. SAMPLE ET AL., supra note 11 , at 9 .

118. Id. at 9 .

119. These ten states are Alabama, Ohio, Pennsylvania, Illinois, Texas, Michigan, Mississippi, Louisiana, Nevada, and West Virginia. See id. at 6 fig.2.

120. See id. at 11 .

121. See id. at 10-11.

122. Id. at 10 .

123. Id. This figure is based on the Author's analysis of the raw data underlying the super spender figures used in the New Politics report. The raw data are on file with the Author.

124. Id. at 9. This further breakdown of the top twenty spenders within the 145 super spenders does not appear within the New Politics report itself, but is a further calculation using the same raw spending data that my Co-Authors and I used for the report. Likewise, the median for expenditures by the 145 super spenders is $\$ 198,016$. The raw data are on file with the Author.

125. Id. 
for at least $25 \%$ of all campaign funding. ${ }^{126}$ In nine elections, five super spenders accounted for more than 50\%, exceeding thousands of contributors combined. ${ }^{127}$ Finally, of the super spenders that laid out more than $\$ 100,000$, only one was an individual: Don Blankenship, whose $\$ 3$ million in expenditures in the 2004 West Virginia election led to Caperton. ${ }^{128}$

Will this super spender trend continue? If so, it will inevitably lead to courtrooms across the country in which the physical separation of the litigation aisle demarks dramatic asymmetries in financial support. Clearly, no one can say for certain, but there is every reason to believe the trends will not only continue, but worsen. Perhaps most tellingly, consider that the above-described sea changes in judicial elections occurred in the pre-Citizens United era, an era in which many states had laws equivalent to the federal bans on spending corporate and union general treasury funds (as opposed to via PACs) on state campaigns. ${ }^{129}$ No such restrictions survive Citizens United, a stark reality that, as Justice John Paul Stevens recognized in dissent, is likely to have a particularly pronounced effect on court campaigns: "At a time when concerns about the conduct of judicial elections have reached a fever pitch, the Court today unleashes the floodgates of corporate and union general treasury spending in these races." 130

\section{E. Case Study: Avery v. State Farm}

Behind these figures are the individual races that drive those numbers. In 2004-the year of the West Virginia campaign that culminated in Caperton-Illinois arguably best exemplified the nexus of pending high-stakes litigation and big-money campaigns. In a race for a seat on the Illinois Supreme Court, two candidates combined to raise more than $\$ 9.3$ million, a figure that was nearly double the previous national record for a state judicial election. ${ }^{131}$ To put the sum in further perspective, $\$ 9.3$ million was also more than was spent in eighteen U.S. Senate races that year. ${ }^{132}$ Moreover, the sums were not necessitated by a costly statewide campaign akin

126. Id.

127. Id.

128. $I d$.

129. Life After Citizens United, National Conference of State Legislatures, http://www.ncsl.org/default.aspx?tabid=19607\#laws (last visited Dec. 28, 2010).

130. Citizens United v. FEC, 130 S. Ct. 876, 968 (2010) (citation omitted) (Stevens, J., concurring in part and dissenting in part).

131. See James Sample, The Campaign Trial: The True Cost of Expensive Court Seats, State, Mar. 6, 2006, http://www.slate.com/id/2137529.

132. GoldBerG ET AL., supra note 88, at 18. 
to a U.S. Senate race. Instead, the Illinois Supreme Court seat in question was elected by a single district-and a rural one at that. ${ }^{133}$ The record sums were less a natural progression than they were a function of litigation timing.

In May 2003, the Supreme Court of Illinois heard oral arguments in the appeal of Avery v. State Farm Mutual Automobile Insurance Company. ${ }^{134}$ "The dispute involved a class action against State Farm on behalf of 4.7 million policyholders in forty-eight states." 135 Although the argument was heard in May 2003, the appeal would not be decided until seventeen months later, after the November 2004 election. In other words, the appeal was pending before the Supreme Court of Illinois-and had been for a year-by the time the 2004 campaign began. ${ }^{136}$ The stakes in Avery were huge. State Farm's appeal sought to overturn a $\$ 1$ billion lowercourt verdict against the insurer, including $\$ 456$ million in contractual damages. ${ }^{137}$

Lloyd Karmeier, the victorious candidate in the race, was supported by $\$ 350,000$ in direct contributions from employees, lawyers, and others (e.g., amici) directly involved with State Farm and/or its pending appeal, and by an additional $\$ 1$ million from larger groups of which State Farm was a member or to which it contributed. ${ }^{138}$

133. $I d$.

134. 835 N.E.2d 801 (Ill. 2005), cert. denied, 547 U.S. 1003 (2006).

135. Sample, supra note 131 .

136. Id.

137. Avery, 835 N.E.2d at 817.

138. For example, Justice Karmeier received $\$ 1.9$ million in contributions from the Illinois Republican Party, which received over $\$ 2$ million from the U.S. Chamber of Commerce. See GoldBerg ET AL., supra note 88, at 26 fig. 17. Employees at State Farm were directors of the U.S. Chamber of Commerce. Justice Karmeier also received nearly $\$ 1.2$ million in contributions from the Illinois Civil Justice League's political committee, JUSTPAC. Sample, Campaign Trial, supra note 131. The largest contributors to JUSTPAC included the American Tort Reform Association $(\$ 415,000)$, the U.S. Chamber and the Illinois Chamber of Commerce $(\$ 200,000)$, and the Coalition for Jobs, Growth and Prosperity $(\$ 150,000)$. See Rachel Weiss, The Institute on Money in State Politics, Fringe Tactics: SpeCial INTEREST Groups Target Judicial Races 11 (2005), available at http:// www.followthemoney.org/press/Reports/200508251.pdf. State Farm was a member of and contributor to both the American Tort Reform Association and the Illinois Coalition for Jobs, Growth and Prosperity. See Petition for Writ of Certiorari at 8 n.3, Avery v. State Farm Mut. Auto. Ins. Co., 547 U.S. 1003 (2006) (No. 05842), 2005 WL 3662258, at *8 [hereinafter "Avery Petition"].

Justice Karmeier's opponent, Judge Gordon Maag, received $\$ 2.8$ million in contributions from the Illinois Democratic Party, $\$ 1.2$ million from Justice For All PAC, and more than $\$ 50,000$ from the Illinois State Federation of Labor. See GoldBerg ET AL., supra note 88, at 19; Avery Petition at 7. The Illinois Democratic 
Immediately upon winning the race, Karmeier called the fundraising in the race "obscene for a judicial race" and queried, some might say deliciously: "What does it gain the people? How can people have faith in the system?" 139 Whatever the answers to the questions were at the time Karmeier posed them, the people's "gain[s]" and "faith in the system" were unlikely to increase when, almost immediately upon taking the bench, Karmeier cast a tie-breaking vote nixing the $\$ 456$ million claim against State Farm. ${ }^{140}$

An editorial in the St. Louis Post-Dispatch reflecting on Avery explained that Justice Karmeier also cast the deciding vote in reversing a $\$ 10.1$ billion judgment against Philip Morris USA. ${ }^{141}$ Reportedly, Philip Morris, along with a business lobbying group backing it, spent more than $\$ 1$ million supporting Karmeier in the 2004 election. ${ }^{142}$ Lawyers, judges, and press around the state and country expressed concerns summed up by the Post-Dispatch's editorial:

The juxtaposition of gigantic campaign contributions and favorable judgments for contributors creates a haze of suspicion over the highest court in Illinois. . . Although Mr. Karmeier is an intelligent and no doubt honest man, the manner of his election will cast doubt over every vote he casts in a business case. This shakes public respect for the courts and the law-which is a foundation of our democracy. ${ }^{143}$

The Avery plaintiffs sought review on due process grounds, and the Supreme Court denied certiorari. ${ }^{144}$ When I analyzed the chances for certiorari at the time, I believed that, short of express criminal bribery, the following circumstances could scarcely get more compelling: (1) the race was the nation's most expensive judicial race ever; (2) the election happened while an appeal was pending before the court-and had been for seventeen months

Party received almost $\$ 2$ million from lawyers and law firms. Justice For All PAC's $\$ 1.2$ million in contributions to Judge Maag constituted the entirety of its political expenditures in 2004. See GoldBerG ET AL., supra note 88, at 27 fig.18. The organization received a combined $\$ 670,000$ from an Illinois law firm, Simmons Firm LLC, and one of its attorneys, Randall A. Bono. Id. Justice for All PAC also received more than $\$ 90,000$ in contributions from attorney Stephen N. Tillery, and a $\$ 50,000$ contribution from attorney Barry Johan. See id.

139. GoldBerg ET AL., supra note 88 , at 19.

140. Sample, supra note 131.

141. Editorial, Buying Justice?, St. Louis Post-DisPatch, Dec. 20, 2005, at B8.

142. Id.

143. Id.

144. Avery v. State Farm Mut. Auto. Ins. Co., 547 U.S. 1003 (2006). By way of disclosure, I served as counsel on an amicus brief in support of certiorari in Avery. 
including the entirety of the campaign; (3) the principal funders were interested parties in the litigation; and (4) the winning candidate then cast an outcome-determinative vote. ${ }^{145} \mathrm{I}$ thus believed these circumstances were enough for the Supreme Court to consider whether due process could be jeopardized by outsized judicial campaign support. Therefore, once the Court denied certiorari, ${ }^{146}$ I believed the Court would almost certainly continue to decline to weigh in on the due process question. Fortunately, as discussed at length in Part III, my analysis proved to be wrong-not only with respect to the question of certioriari on the issue, but also with respect to whether the brave new world of judicial elections would produce an even more egregious scenario.

It is worth noting briefly here that one of the most interesting (and essentially unnoticed) distinctions between Avery and Caperton pertains specifically to the issue of the Buckley contribution-expenditure dichotomy. In Avery, even the large contributions, while funneled through a variety of political action committees, trade groups, and umbrella organizations, ultimately made their way to the candidates as direct contributions. This was made possible by the fact that Illinois had no state contribution limits whatsoever, symptomatic perhaps of a certain kind of state politics. On the contrary, under West Virginia law, an individual may give no more than $\$ 1000$ per election cycle to a campaign. ${ }^{147}$ Thus, in 2004, Don Blankenship contributed the $\$ 1000$ maximum to his favored candidate's campaign ${ }^{148}$ and then spent $\$ 3$ million to support that candidate the only ways he legally could-by personal independent expenditures and via a 527.149 By way of contrast, equivalent sums were given to the candidates in Avery directly. ${ }^{150}$

Comparing Avery and Caperton thus highlights that from a Buckley standpoint, for all their similarities, significant differences exist regarding the monetary sources and forms at issue. In Avery, the pertinent spending came in the form of direct contributions from concentrated, though still comparatively dispersed sources. In

145. See Brief for 12 Organizations Concerned About the Influence of Money on Judicial Integrity, Impartiality, and Independence as Amici Curiae Supporting Petitioners at 3, 9, 19-20, Avery, 547 U.S. 1003 (No. 05-842), 2006 WL 295175, at *3, *9, *19-20; see also Sample, supra note 131.

146. Avery v. United States, $130 \mathrm{~S}$. Ct. 766 (2009).

147. W. VA. Code ANN. \$ 3-8-12(f) (West 2010).

148. Caperton v. A.T. Massey Coal Co., 129 S. Ct. 2252, 2257 (2009).

149. See infra Part III (detailing legal categorizations of Mr. Blankenship's expenditures).

150. See supra note 138 . 
Caperton, the pertinent support came exclusively in the form of independent expenditures, but entirely from one individual.

This approach would leave a wise but not wealthy candidate for judicial office who faces a substantial independent expenditure campaign with essentially three options: (1) subtly and sometimes not so subtly signaling a favorable disposition towards other organized, concentrated interests-a clear abdication of the ideals of the judicial role; ${ }^{151}$ (2) the daunting and statistically almost impossible specter of raising enough money to meaningfully counter the funded speech-even inaccurate funded speech without engaging in option (1); or (3) surrender-often before ever entering a race at all, thereby creating an adverse selection problem that degrades the quality of the courts, even apart from concerns about their impartiality.

III.

\section{“CAPERTON CONTRIBUTIONS” AND DUE PROCESS}

Part III of this Article coins the term "Caperton contributions" to describe the equation of independent expenditures with contributions in the judicial elections context. As Justice Stevens articulates in dissent in Citizens United, Caperton "underscores the old insight that, on account of the extreme difficulty of proving corruption, 'prophylactic measures, reaching some campaign spending not corrupt in purpose or effect, may be nonetheless required to guard against corruption." "152 Justice Stevens, of course, is using Caperton to argue for such prophylactic measures in the non-judicial elections context, where there is no commitment to impartiality, and where there is an entirely different democratic expectationnamely, of constituent influence, including moderate influence via contribution-limited financial support. In the context of the courts, financial influence itself is a concern, as is the perception thereof. Part III of this Article thus argues that just as the difficulty of prov-

151. Professor Karlan recently described this dynamic as follows:

Money can play a critical role in judicial elections. Especially because many judicial elections are low-salience, down-ballot races, political spending often serves as the major source of information to voters. Just as judicial candidates may face a temptation to shade their decisions to attract voters' support, so too they may face the temptation to shade their decisions to attract the financial support that enables them to appeal to voters.

Pamela S. Karlan, Electing Judges, Judging Elections, and the Lessons of Caperton, 123 HARV. L. Rev. 80, 90 (2009) (citation omitted).

152. Citizens United v. FEC, 130 S. Ct. 876, 968 (2010) (Stevens, J., concurring in part and dissenting in part) (quoting Buckley v. Valeo, 424 U.S. 1, 30 (1976)). 
ing corruption justifies prophylactic measures, the differences in democratic expectations in the courts as compared to the constituent branches justify differential treatment of expenditures in a judicial elections context. Given the controversial and compelling equation of expenditures and contributions in Caperton, this Article coins the term "Caperton contributions" to provide a prospective shorthand for just such differential treatment.

\section{A. Facts That Push Formalism Beyond Its Limits}

In August 2002, a West Virginia jury returned a verdict that found A.T. Massey Coal Co. and its affiliates liable for fraudulent misrepresentation, concealment, and tortious interference with existing contractual relations. ${ }^{153}$ The jury awarded plaintiffs Hugh Caperton, Harman Development Corp., Harman Mining Corp., and Sovereign Coal Sales the sum of $\$ 50$ million in compensatory and punitive damages. ${ }^{154}$ During the consideration of post-verdict motions and just prior to appealing the verdict to West Virginia's sole appellate court, Massey's chairman, chief executive officer, and president, Don Blankenship, spent approximately $\$ 3$ million in 2004 supporting attorney Brent Benjamin in a campaign against an incumbent of that court, West Virginia Supreme Court of Appeals Justice Warren McGraw. ${ }^{155}$

Blankenship contributed $\$ 1000$, the statutory maximum under West Virginia law, to Benjamin's campaign. ${ }^{156}$ Additionally, he spent $\$ 517,707.53$ in his own name “to support" Justice Benjamin's candidacy, including via radio and newspaper advertisements, campaign fliers, and telephone calls to registered voters. ${ }^{157}$ Most substantially, Blankenship donated almost $\$ 2.5$ million to a 527 organization named "And For The Sake Of The Kids," which supported Benjamin and/or attacked McGraw. ${ }^{158}$

Finally, though it is much less easily quantified both by nature and intent, Blankenship-as the CEO of one of the largest compa-

153. Caperton, 129 S. Ct. at 2254.

154. Id. at 2257 .

155. Id.

156. Id.

157. Id. (quoting Blankenship's state campaign financial disclosure filings). Mr. Blankenship's $\$ 3$ million in expenditures were, by legal definition, for the purpose of influencing the election. Mr. Blankenship spent $\$ 517,707$ that he reported to the state as "expenditures" on W. Va. Official Form F-7B. Form F-7B is used only to report an expenditure "for a communication which expressly advocates the election or defeat of a clearly identified candidate . ..." See W. VA. CODE ANN. §3-81a(15) (West 2010) (defining "independent expenditure").

158. See Caperton, 129 S. Ct. at 2257. 
nies in the state-was instrumental in helping to raise additional money contributed to the 527, as well as a significant portion of the roughly $\$ 800,000$ amassed by the "official" Benjamin campaign. In little noticed but startling comments-particularly from a juristjust prior to oral argument in the U.S. Supreme Court, former West Virginia Chief Justice Richard Neely described Blankenship's less quantifiable efforts:

Just factually, Massey Coal buys a lot of stuff. It buys mine gear. It buys . . . equipment. It buys Caterpillars. Blankenship knocked down every person Massey did business with, for the purpose of raising money to go into this 527 . The 527 , as a matter of fact, was supremely well coordinated with Justice Benjamin's campaign. And Massey saw to it that clean, reportable contributions from all kinds of people that nobody ever heard of-little old ladies in tennis shoes, right - who were the mothers of people who owned equipment suppliers, right, went to Benjamin himself so that he could put up huge billboards that said, "Who is Brent Benjamin?"-Just, name recognition, to get the campaign off the ground. ${ }^{159}$

Even completely setting aside money he might have raised through these less than salutary methods, however, Blankenship's expenditures were substantial. Blankenship's spending accounted for $60 \%$ of all expenditures in support of Benjamin's candidacy. Blankenship was thus very much a "super spender." Indeed, Blankenship was the principal financial force behind Benjamin's campaign. Benjamin defeated the incumbent McGraw; he then repeatedly refused to disqualify himself from the multimillion-dollar Massey case, although West Virginia's Code of Judicial Conduct required Justice Benjamin's disqualification whenever his impartiality "might reasonably be questioned." 160

159. Press Release, American Constitution Society, Judicial Elections and Due Process: On Caperton v. A.T. Massey Coal Company, et al. (Feb. 26, 2009), available at http://www.acslaw.org/node/8257.

160. See W. Va. Code of Judicial Conduct Canon § 3(E) (1) (2010) (requiring a judge to "disqualify himself or herself in a proceeding in which the judge's impartiality might reasonably be questioned"); see also James Sample, David Pozen \& Michael Young, Fair Courts: Setting Recusal Standards 17-18 (Brennan Center for Justice 2008), available at http://brennancenter.org/content/resource/fair_courts_setting_recusal_standards/ (noting near universality of this standard in the states). I have asserted the relatively non-controversial proposition that, while the "myriad extreme facts in the case presented the Court with a landmark question of constitutional law ... it was an easy state question that gave birth to the difficult federal issue." James Sample, Caperton: Correct Today, Compelling Tomorrow, 60 SyRACuSE L. REV. 293, 294 (2010). 
Instead, in November 2007, Benjamin voted in a 3-2 majority to overturn the jury's verdict against Massey; after the decision, he had unusually plentiful opportunities to reconsider his refusal to disqualify himself. Previously undisclosed photographs were uncovered that showed Blankenship's coziness with the court extended beyond Benjamin himself. In January 2008, photos surfaced depicting Blankenship and another member of the 3-2 majority, thenChief Justice Elliot Maynard, vacationing together in the French Riviera during the pendency of Blankenship's company's appeal. ${ }^{161}$ After these photos were discovered and published on front pages of newspapers across the country, ${ }^{162}$ Maynard stepped down from the case. ${ }^{163} \mathrm{He}$ nonetheless asserted he had remained impartial all along. Blankenship's cozy relationship with Maynard and his separate support of Benjamin led still a third Justice to take the unusual step of criticizing Blankenship-the CEO of a litigant before the court-and his own colleagues. Larry Starcher, one of the original dissenting justices in that 3-2 decision, decried what he termed the "cancer" of moneyed influence in his court. He further asserted that "John Grisham got it right when he said that he simply had to read the Charleston Gazette to get an idea for his next novel." ${ }^{64} \mathrm{He}$

161. Caperton, 129 S. Ct at 2258.

162. See, e.g., Adam Liptak, Motion Ties W. Virginia Justice to Coal Executive, N.Y. Times, Jan. 15, 2008, available at http://www.nytimes.com/2008/01/15/us/ 15 court.html.

163. Caperton, $129 \mathrm{~S}$. C. at 2258.

164. Id. The details of each of the recusal motions are beyond the scope of this article, which is focused prospectively on the issue of independent expenditures as opposed to a retrospective just on Caperton itself. It is worth noting, however, that Benjamin's denials were accompanied by memoranda reflecting a complete lack of understanding of the rule-based, as opposed to constitutionally based disqualification rules. Jeffrey Stempel recently wrote an excellent analysis to this end; Stempel's analysis focused on Benjamin's assertion that "no objective information" had been advanced demonstrating that Benjamin would actually be biased. Stempel incisively notes the following:

[Benjamin's] memorandum establishes that he misunderstood-or did not want to understand-what is meant by the objective test for recusal. Instead of focusing on what outside observers would think based on their observations (for example, $\$ 3$ million in campaign support from interested de facto party for judge deciding case important to benefactor), Justice Benjamin instead seems to view the objective test as a matter of whether he personally is persuaded by the motion for recusal, notwithstanding whatever number of reporters, editorialists, or commentators may disagree. In addition, Justice Benjamin appears to focus primarily on whether he is biased or prejudiced, giving implicit short shrift to the correct standard of impartiality. Even when nodding in this direction, Justice Benjamin mangles the concept. He states that recusal is not required because there is insufficient evidence to prove that he would fail to be fair and impartial-but the correct inquiry is whether ob- 
then disqualified himself from the case, urging Benjamin to do likewise. ${ }^{165}$

Subsequently, the West Virginia Supreme Court, with two substitute judges replacing Starcher and Maynard, re-heard the appeal. Benjamin once again voted in a 3-2 majority to overturn the verdict against Massey. Hugh Caperton and Harman Mining successfully sought certiorari in the U.S. Supreme Court, arguing that Benjamin's failure to recuse himself violated the Fourteenth Amendment's guarantee of Due Process. ${ }^{166}$

\section{B. Caperton and the Buckley Conundrum}

1. Framing the Issue Before the Court

The petitioners in Caperton, led by Ted Olson, clearly and correctly characterized Blankenship's support for Benjamin as independent expenditures, i.e., they were on the wrong side of the Buckley dichotomy. For example, in their merits stage brief before the Court, Petitioners stated that "Mr. Blankenship contributed the maximum amount permitted by West Virginia law to Benjamin's campaign committee. He then spent 3,000 times that amountsome $\$ 3$ million - to underwrite independent advertisements supporting Benjamin, while publicly urging others to make additional donations to the campaign." 167 Then, in attempting to refute Benjamin's own contention that his "campaign was completely indepen-

servers would harbor doubts about his impartiality. Instead of playing by the rules and correctly applying the proper standard, Justice Benjamin imposes a burden not required by law-the burden to prove that he cannot be impartial.

Jeffrey W. Stempel, Impeach Brent Benjamin Now!? Giving Adequate Attention to Failings of Judicial Impartiality, 47 SAN DiEGo L. Rev. 1, 38 (2010) (internal citations omitted). Under the circumstances, the rule-based necessity of Benjamin's disqualification was apparent to virtually all involved-except Benjamin himself. In dissent on the constitutional ruling requiring Benjamin's disqualification, Justice Scalia, for example, nonetheless noted that that it is " $[u]$ ndoubtedly" clear that "[i]n the best of all possible worlds" judges should "sometimes recuse even where the clear commands of . . due process law do not require it. . . . See Caperton, 129 S. Ct. at 2275 (Scalia, J., dissenting).

165. See Voluntary Disqualification of Justice Larry V. Starcher, A.T. Massey Coal Co. v. Caperton, 679 S.E.2d 223, (W. Va. 2008) (No. 33350), available at http://www.state.wv.us/wvsca/press/caperton.pdf.

166. See infra Part IV.A (addressing in depth close interrelationship that exists between due process clause, judicial elections, and public's strong desire for fair and impartial judiciary).

167. Brief for Petitioners at 2, Caperton v. A.T. Massey Coal Co., 129 S. Ct. 2252 (2008), 2008 WL 5433361. 
dent of any independent expenditure group,"168 the petitioners contended further that the "debt of gratitude in the case [was] not diminished" merely by the fact that Blankenship's support involved independent expenditures because the "end result was the same: Mr. Blankenship's expenditures were directly responsible for hundreds of pro-Benjamin and anti-McGraw campaign advertisements that unquestionably helped Justice Benjamin-a previously unknown and underfunded candidate-prevail in his sharply contested race." 169 Amici in support of Caperton also emphasized the fact that the majority of Blankenship's support for Benjamin came in the form of independent spending. ${ }^{170}$

For Massey, however, Buckley formalism trumped the facts. Accordingly, Massey argued to the Court that "Blankenship contributed only $\$ 1,000$ directly to Benjamin's campaign. Apart from a $\$ 1,000$ contribution by A.T. Massey Coal Company's PAC neither Massey nor any of its subsidiaries contributed money to Benjamin's campaign." 171 Phrased differently, arguing from Buckley, the focus of the case was a garden variety $\$ 1000$ campaign contribution, while the elephant in the room-three-million dollars in independent support-was but an inconsequential footnote. If this proposition strikes one as absurd, it is all the more remarkable that, as noted in the introduction to this Article, precisely such a result would have obtained were it not for Justice Kennedy's vote. ${ }^{172}$ In fact, Chief Justice Roberts's dissent fully embraces and endorses the Alice in Wonderland qualities of a rigidly-applied Buckley contributions-expenditures distinction, such that the operative expenditure was $\$ 1000$ rather than $\$ 3$ million as follows: "It is true that Don Blankenship spent a large amount of money in connection with this election. But this point cannot be emphasized strongly enough: Other than a $\$ 1000$ direct contribution from Blankenship, Justice Benjamin and his campaign had no control over how this money was spent." 173 Further playing the independent and uncoordinated

168. Id. at 34 .

169. Id. at 17-18.

170. See, e.g., Brief of the Brennan Center for Justice at NYU School of Law et al. as Amici Curiae Supporting Petitioners at 23, Caperton, 129 S. Ct. 2252 (No. 0822), 2009 WL 45972 (asserting that “[a]s a practical matter, distinctions between contributions and expenditures have only marginal salience when it comes to the fundamental fairness concerns at the core of due process").

171. Brief for Respondents at 4, Caperton, 129 S. Ct. 2252 (No. 08-22), 2009 WL 216165.

172. Caperton, 129 S. Ct. at 2256 (2009).

173. Id. at 2273 (Roberts, J., dissenting). Legal ethics expert Keith Swisher recently wrote an excellent piece in which he "respectfully dissent[ed] from the 
card, Massey argued that Blankenship "did not and does not have any friendship or other personal connection with Benjamin, and [that Blankenship's] support was not solicited by [Benjamin]."174 As it happened, this latter assertion proved to be an instance of extraordinarily bad lawyering; the contention was not only demonstrably false, but was directly contradicted in the New York Times by, of all people, Blankenship himself, who said that that he and Benjamin had indeed met privately before the election; discussed the campaign; and specifically discussed, inter alia, "raising money." 175 Worse, the false assertion in Massey's brief was then repeated at oral argument. ${ }^{176}$ The Massey brief went so far as to deny that Blankenship and Benjamin "even knew one another, before or after the election." 177

Massey's lawyers' stunning misrepresentations about their own client in this regard were compounded by an equally bizarre strategic error. Immediately following oral argument in the U.S. Supreme Court, Massey's lawyers sought leave to submit a supplemental brief to bring to the Court's attention a transparently self-serving press release from the West Virginia Supreme Court of Appeals' public information office-an office which was subject to oversight by Benjamin in his new capacity as Chief Justice. ${ }^{178}$

dissent" stating that "every question, save one or two, can be answered (and the ones that cannot seem to reflect more poorly on the questioner's drafting than the majority's analysis)." Posting of Keith Swisher to Judicial Ethics Forum, Caperton: Answers to the Chief Justice's “Twenty Questions" Times Two (June 15, 2009), http:// judicialethicsforum.com/2009/06/15/caperton-answers-to-chief-justice-robertstwenty-questions-times-two. Swisher also noted that "an umpire who merely calls balls and strikes should be less concerned with questions not before the court, and indeed, [that] every case could spawn a multitude of forward-looking questions not raised by the facts at hand. ..." Id. Swisher's article goes on to propose answers to each of the 40 questions, and should be considered a must-read for those interested in the case.

174. Id. at 3 .

175. Adam Liptak, Justices Hear Arguments on Money-Court Nexus, N.Y. TIMEs, Mar. 4, 2009, at A18, available at http://www.nytimes.com/2009/03/04/washing ton/04scotus.html?_r=1.

176. Transcript of Oral Argument at 30, Caperton v. A.T. Massey Coal Co., 129 S. Ct. 2252 (2009) (No. 08-22), 2009 WL 527723 [hereinafter “Caperton Transcript"].

177. Brief for Respondents at 55, Caperton v. A.T. Massey Coal Co., 129 S. Ct. 2252 (2009) (No. 08-22), 2009 WL 216165.

178. Supplemental Brief for Respondents at 1, Caperton v. A.T. Massey Coal Co., 129 S. Ct. 2252 (2009) (No. 08-22) (citing Press Release, Supreme Court of Appeals, State of West Virginia, Summary of Chief Justice Benjamin's Dispositive Voting Record Regarding Massey Energy Cases from 01/01/2005 to 12/31/2008 (Mar. 2, 2009), available at http://www.state.wv.us/wvsca/press/march2_09.htm), 
Massey's gambit opened the door for Olson and Caperton to oppose the motion on the ground that the press release, consisting as it did of merely recycled arguments, failed to meet the standard for "new matter" deserving of the Court's attention. ${ }^{179}$ Olson adroitly noted that, in contrast to the recycled press release, Blankenship's interview with the Times-conducted weeks earlier-was effectively made new all over again because Andrew Frey, Massey's lawyer, expressly denied before the U.S. Supreme Court a fact that his own client had expressly admitted to the press. Frey's denial was perhaps unwitting or perhaps strategic. Either way, it was clearly unwise. Indeed, the exchange was remarkable enough to those paying close attention that Liptak, acting in his capacity as the Supreme Court reporter for the Times, included the following passage in his story the day after the oral argument:

Justice Scalia explored the nature of the relationship between Mr. Blankenship and Justice Benjamin.

"This contributor never even met the judge, did he?" Justice Scalia asked Mr. Olson, who said the answer was not clear.

Justice Scalia's question appeared to be based on an assertion in a brief Massey filed with the court in January. It said "there is no indication that Blankenship and Justice Benjamin even knew one another, before or after the election."

But Mr. Blankenship said in an interview last month that he had met with Mr. Benjamin before the election. Mr. Blankenship said that his spending had been mainly intended to oust the incumbent justice, Warren McGraw, but that he nonetheless wanted to meet the justice's opponent.

"I thought, if I want to beat this guy I ought to know who's running against him," Mr. Blankenship said, adding that the meeting did not go well.

"When he got through talking to me, I said, "Mr. Benjamin, I don't know who you are, but if you go around talking to business people about raising money, you need to do more listening than you do talking," Mr. Blankenship recalled. ${ }^{180}$

The above sequence, especially when viewed through the lens of former Chief Justice Neely's comments, reflects much more than

available at http://www.abanet.org/publiced/preview/briefs/pdfs/07-08/0822_RespondentSuppmotion.pdf.

179. Opposition to Respondents' Motion for Leave to File a Supplemental Brief at 1, Caperton v. A.T. Massey Coal Co., 129 S. Ct. 2252 (No. 08-22), available at http://www.abanet.org/publiced/preview/briefs/pdfs/07-08/08-22_Petitioner OpptoMotionSupp.pdf.

180. Liptak, supra note 175 . 
just the inside baseball of one particular case. Indeed, the sequence raises a common sense question germane to independent campaigns more generally. As a practical matter, just how surprising is it that a de jure uncoordinated $\$ 3$ million "independent" campaign would be coordinated de facto? Even the fabulously wealthy are unlikely to spend millions on the metaphorical complete mystery behind door number two. Suffice it to say that the only distinctions making the Caperton scenario unique in this respect are that usually, the person or entity responsible for spending the millions is hardly inclined to admit coordination (or near coordination) to the New York Times. Moreover, if they were to do so, it is even less likely that their lawyer (with honest ignorance being the best-case explanation) would contradict the client in briefs and oral presentations to the U.S. Supreme Court.

Speaking on the same panel as former West Virginia Chief Justice Richard Neely, judicial ethics scholar Amanda Frost adeptly framed Blankenship's activities relationship to the dynamics of judicial campaigns more generally:

Blankenship recently gave an interview to the New York Times where he admitted .... [that] "w[e] set it up to make Justice McGraw look bad on issues involving children. We found a case where he released someone who was accused of being a pedophile, we publicized that case, and he said, "but that was not why I started this organization. I started And For the Sake of Kids to get McGraw off the court because I wanted someone who could protect my corporate interests."

That's I think the most disturbing thing about this case because it's happening not just in West Virginia, it's happening in many, many states. People take a hot-button issue-like releasing somebody early from a sentence, or some pedophile getting out of jail ... . and use that as a means to try to get someone into office who they think will benefit them financially. ${ }^{181}$

To a certain extent, the portion of Frost's second paragraph relating to the content of the campaigns accurately details a mix of the unfortunate and the inevitable-and a reality about which little

181. Amanda Frost, Press Briefing on Caperton v. A.T. Massey Coal Company, et al., American Constitution Society: Judicial Elections and Due Process, at 56:20 (Feb. 26, 2009), available at http://www.acslaw.org/node/8257. Professor Keith Swisher has noted that "the tough-on-crime message, or some derivation thereof, is among the most, if not the most, prevalent in judicial campaigns." Keith Swisher, Pro-Prosecution Judges: "Tough on Crime," Soft on Strategy, Ripe for Disqualification, 52 Ariz. L. Rev, 317, 327 (2010). 
can (or should) be done from a regulatory standpoint. Judicial selection, regardless of whether via appointment or election, involves politics, including aspects of the mess of politics. Too often, critics of judicial elections - and they have much to criticize-argue from the false premise that elections have cornered the judicial selection market for unseemliness, a lack of transparency, and misdirection. Would that it were so. ${ }^{182}$ Still, the distortional dynamics that Frost correctly describes are greatly exacerbated by big money election expenditures. Which is to say that it is a simple fact that, absent content regulation (a "cure" worse than the disease), misinformation is inevitable. Yet regardless of whether the information is accurate or misleading, two facts are indisputable: (1) unlimited millions of dollars can disseminate a whole lot more of it than can, for example, thousands of dollars; and (2) the candidates, against whom big-money independent expenditure campaigns are waged, have limited places to turn for the money required to respond, with key stakeholders before the bench being by far the most fertileand independence threatening-sources.

\section{Sub Silentio Genius}

A rigid, formalistic application of Buckley's contribution-expenditure distinction in Caperton would have resulted in exactly the position that Massey advocated-Blankenship's trivial $\$ 1000$ contribution would not have triggered recusal even under the ethics rules, much less under the Due Process Clause. The $\$ 3$ million in expenditures would simply not have been relevant. Opening the Pandora's Box of directly challenging Buckley's contribution-expenditure distinction, however, was not an option in Caperton-and certainly would not have been a winning option had it been pressed. ${ }^{183}$ Moreover, Caperton occurred just seven years after the Court's decision in Republican Party of Minnesota v. White. ${ }^{184}$ In White, the Court held that Minnesota's "announce clause," which prohibited a "candidate for a judicial office" from "announc[ing]

182. See Brennan Center for Justice at New York University School of Law, Testimony of Adam Skaggs on MD Judicial Elections and Senate Bill 833 (Mar. 9, 2010), http://www.brennancenter.org/content/resource/testimony_of_adam_skaggs_ on_md_judicial_elections_and_senate_bill_833/ (noting that merit systems do not of themselves provide guarantee of transparent, independent judiciary).

183. Note, in this regard, that even the far narrower ground that was ultimately pursued produced only a 5-4 victory for the Petitioners. Caperton, $129 \mathrm{~S}$. Ct. at 2252 (2009).

184. 536 U.S. 765 (2002). 
his or her views on disputed legal or political issues," 185 violated the First Amendment. ${ }^{186}$ The Court left little doubt that, despite the due process interest, much speech surrounding judicial campaigns was identical to that surrounding legislative and executive elections, at least inasmuch as it was protected by the First Amendment. Most notably, for our purposes of analyzing Caperton, Justice Kennedy concurred in White, stating:

[Minnesota] may strive to define those characteristics that exemplify judicial excellence. It may enshrine its definitions in a code of judicial conduct. It may adopt recusal standards more rigorous than due process requires, and censure judges who violate these standards. What Minnesota may not do, however, is censor what the people hear as they undertake to decide for themselves which candidate is most likely to be an exemplary judicial officer. Deciding the relevance of candidate speech is the right of the voters, not the State. ${ }^{187}$

White made it clear that in judicial elections-just as in legislative or executive contests- "[d] ebate on the qualification of candidates" lies "at the core . . . of First Amendment freedoms, not at the edges." 188 White, however, dealt with speech qua speech as opposed to money qua speech. Justice Scalia's opinion for the Court in White stated, inter alia, that: "We neither assert nor imply that the First Amendment requires campaigns for judicial office to sound the same as those for legislative office." 189 Still, White reinforced the notion that the Buckley split would apply to judicial and non-judicial contexts in exactly the same manner.

In Caperton, however, Justice Kennedy proved unwilling to push Buckley formalism to what would have been an illogical and untenable result. Rather than confronting the Buckley conundrum, or delving into the thicket of just how different judicial elections should or should not be, the Court narrowly held (5-4) that Benjamin's participation violated the Due Process Clause of the Fourteenth Amendment. For present purposes, the italicized text is intended to highlight the Court's treatment of the Buckley distinction vis-à-vis the holding in Caperton:

To provide some perspective, Blankenship's $\$ 3$ million in contributions were more than the total amount spent by all other

185. Id. at 768 (quoting 52 Minn. Code of Judicial Conduct Canon $5(\mathrm{~A})(3)$ (d) (i) (2000)).

186. Id. at $774-84$.

187. Id. at 794 (Kennedy, J., concurring).

188. Id. at 781 (internal quotations omitted).

189. Id. at 783 . 
Benjamin supporters and three times the amount spent by Benjamin's own committee. ${ }^{190}$

There is a serious risk of actual bias-based on objective and reasonable perceptions-when a person with a personal stake in a particular case had a significant and disproportionate influence in placing the judge on the case by raising funds or directing the judge's election campaign when the case was pending or imminent. The inquiry centers on the contribution's relative size in comparison to the total amount of money contributed to the campaign, the total amount spent in the election, and the apparent effect such contribution had on the outcome of the election. ${ }^{191}$

Just as no man is allowed to be a judge in his own cause, similar fears of bias can arise when-without the consent of the other parties - a man chooses the judge in his own cause. And applying this principle to the judicial election process, there was here a serious, objective risk of actual bias that required Justice Benjamin's recusal. ${ }^{192}$

To say that it did not take long for campaign finance experts to focus on Caperton's treatment of Blankenship's nominal independent expenditure as a contribution would be an understatement. Perhaps the best, and certainly the quickest example, is the post by Rick Hasen described at this start of the Article, suggesting that the "equating" of independent expenditures and campaign contributions in the Caperton opinion was "inadvertent."193 On the contrary, Justice Kennedy's equation of Blankenship's expenditures with contributions was clearly intentional and enabled a victory for fact over formalism, a first-of-its-kind acknowledgment that in the judicial elections context, big money spending-whether in the form of contributions or expenditures-implicates not only the First Amendment but due process as well.

Critics pounced. Ronald Rotunda decried that Justice Kennedy "never explains why he blurred the distinction between contributions and expenditures. All we know is that Kennedy acknowledges (only once) that Blankenship engaged in "independent expenditure." But then, a dozen times he repeatedly re-labels these "inde-

190. Caperton v. A.T. Massey Coal Co., 129 S. Ct. 2252, 2257 (2009) (emphasis added).

191. Id. at 2263-64 (emphasis added).

192. Id. at 2265 (emphasis added).

193. Hasen, supra note 3. 
pendent expenditures" as "contributions." 194 Rotunda's frustration is that Justice Kennedy "treats the two words as synonyms and never explains why." 195 Fair enough, but Rotunda goes further, asserting that "[o]ne can understand the concern ... that parties or their lawyers may try to 'buy' a judge with their campaign contributions to their favorite candidate, but that could not have occurred in this case because no party, no litigant, no lawyer, and no one else connected to the Caperton case gave more than $\$ 1,000$, the statutory maximum." 196 Translation: pay no attention to the $\$ 3$ million behind door number two.

Likewise, ardent campaign finance regulaticn opponent Brad Smith ${ }^{197}$ notes that " $[\mathrm{b}]$ efore Caperton, the U.S. Supreme Court had explicitly rejected the argument that Congress may restrict the funding of independent activity that merely 'benefits' a candidate." 198 While this is a valid characterization of the Court's jurisprudence, like Rotunda, Smith goes further. He asserts the following:

Kennedy goes along with the popular press descriptions of the facts and some of the briefs supporting Caperton. These descriptions ... routinely describe Blankenship's activity in terms of "contributions," "contributed," etc., and Justice Kennedy's opinion likewise calls Blankenship's expenditures "contributions." Collapsing the distinction may reflect poor draftsmanship or even a poor understanding of the facts. It may even reflect a willingness to abandon the contribution/expenditure distinction at the center of post-Buckley campaign finance law. ${ }^{199}$

Note the strategic framing at work here. Smith presents the issue as if Justice Kennedy-not only a Supreme Court Justice, but a First Amendment stalwart, particularly in his opposition to cam-

194. Ronald D. Rotunda, Judicial Disqualification in the Aftermath of Caperton v. A.T. Massey Coal Co., 60 Syracuse L. Rev. 247, 262 (2010) (citing Caperton, 129 S. Ct. at 2256).

195. Id. at 263.

196. Id. at 258 (emphasis added).

197. See Bradley A. Smith, Faulty Assumptions and Undemocratic Consequences of Campaign Finance Reform, 105 YALE L.J. 1049 (1996).

198. Stephen M. Hoersting \& Bradley A. Smith, Speech and Elections: The Caperton Caper and the Kennedy Conundrum, 2008-09 Cato Sup. CT. Rev. 319, 335 (2008). Smith's paper is co-authored with Stephen Hoersting, who works for the Center for Competitive Politics, an organization founded and chaired by Smith to advocate against campaign finance regulations. Center for Competitive Politics, About Us, http://www.campaignfreedom.org/about_us/ (last visited Jan. 1, 2011).

199. Hoersting \& Smith, supra note 198, at 344 . 
paign finance regulation-is merely passively "going along with the popular press." For Smith and those who share his perspective, Justice Kennedy's "use of [contribution] nomenclature may allow the Court to escape the logical problems for the protection of independent expenditures that seem to have been created by the ruling in Caperton." 200 Reasonable people can and do disagree about many aspects of campaign finance jurisprudence. However, it is worth pausing to query whether, from a satellite perspective, the "logical problems" that "have been created" have Caperton (which treats $\$ 3$ million in campaign support as consequential) as their creator, or Smith's reading of Buckley (which treats $\$ 3$ million as inconsequential)?

Similarly, James Bopp, who successfully argued White in the Supreme Court, argues that " $[c]$ onstruing Caperton beyond its legitimate scope" will lead to a circumstance in which "third party political speech during judicial campaigns will be chilled because those wishing to contribute or spend their own money to support a candidate . . . will refrain from doing so because it may somehow interfere with a judicial candidate's ability to serve as a judge."201 For this argument, only one Amendment exists-the First. Further, only one interest-anti-corruption-is implicated by independent expenditures in the judicial elections context. Bopp states: "Corruption is a serious charge and serious charges demand serious evidence, particularly where one must overcome the presumption of impartiality accorded to judges. The government has the affirmative burden of demonstrating that its regulation of campaign finance minimizes corruption. Yet it has failed to meet this burden."202 Caperton properly leaves many questions unanswered. However, among the matters that Caperton expressly does settle is that that both of the above propositions are now wrong as a matter of settled law.

First, if a third party is indeed chilled from engaging in substantial, disproportionate spending, it will not be because that spending somehow interferes with a judicial candidate's ability to serve as a judge generally-but rather, only because the would-be spender recognizes that such financial support specifically interferes with the judge's fitness to rule in the benefactor's own case. Second, Caperton makes clear that corruption is not the only inter-

200. Id.

201. James Bopp, Jr. \& Anita Y. Woudenberg, Extreme Facts, Extraordinary Case: The Sui Generis Recusal Test of Caperton v. Massey, 60 Syracuse L. Rev. 305, 305, 335 (2010).

202. Id. at 313. 
est that justifies balancing the First Amendment against other constitutional concerns. This reality, evident throughout the opinion, was perhaps most prominently foreshadowed by Justice Kennedy's statement to Massey's counsel at oral argument:

I want you to be able to elaborate your full theory of the case, but just so you know, it-it does seem to me that the appearance standard has-has much to recommend it. In part it means that you don't have to inquire into the actual bias; it'sit's more objective. Now, of course it has to be controlled, it has to be precise. But I just thought that you know that I-I do have that inclination. ${ }^{203}$

When Massey's counsel argued in response that Due Process cannot rest on appearances, Justice Kennedy replied: "But our whole system is designed to ensure confidence in our judgments. . . . And it seems-it seems to me litigants have an entitlement to that under the Due Process Clause."204

Drawing on this exchange from oral argument, Jed Shugerman points out that "[f]rom these unambiguous signals, it appears that an 'appearance of bias' standard had five votes as of March 3, 2009." 205 Shugerman notes that while the Court's holding somewhat backed away from this reliance on appearances for purposes of Due Process analysis in favor of a "probability of actual bias" standard, this switch has the attribute of "seem[ing] to address real harm without having to prove something so inherently subjective." 206 The shift, however, may have been more significant given that Justice Kennedy frames the issue being decided as whether there is a "serious risk of actual bias-based on objective and reasonable perceptions." 207 In any event, the notion that "corruption" remains the only predicate for the consideration of interests other than the First Amendment is, after Caperton, demonstrably false.

Despite the isolated criticism from advocates of unlimited monetary influence in campaigns such as Smith and Bopp, the Caperton decision-including its treatment of massive independent expenditures-closely tracked the analysis suggested by, among others, Caperton's counsel Ted Olson, whose credentials as a con-

203. Caperton Transcript, supra note 176 , at 33 .

204. Id. at 37.

205. Jed Handelsman Shugerman, In Defense of Appearances: What Caperton v. Massey Should Have Said, 59 DePaul L. Rev. 529, 541 (2010).

206. Id.

207. Caperton v. A.T. Massey Coal Co., 129 S. Ct., 2262, 2263 (2009). 
servative lawyer are unrivaled. ${ }^{208}$ Moreover, the counsel of the Conference of Chief Justices submitted the most remarkable brief in the case. The brief on behalf of the Conference of Chief Justices stated, in essence, four things: (1) "the Constitution may require the disqualification of a judge in a particular matter because of extraordinarily out-of-line campaign support from a source that has a substantial stake in the proceedings"; 209 (2) "[b]ecause the applicability of the Due Process Clause in the campaign spending context depends on the particular facts of each case, no bright-line rule can or should be attempted"; 210 (3) fears that a ruling constitutionally requiring disqualification would "open the floodgates"-such as those ultimately articulated by Chief Justice Roberts and Justice Scalia-were "unfounded";211 and (4) "due process review . . . would be limited to cases of extraordinary support." 212

The CCJ's brief marked the first time in the Conference's sixdecade history as an organized entity that it had filed an amicus brief in a case involving review of a state court judgment-that is to say, in effect, one of its own. Consequently, given that judicial pedigree, the Supreme Court's ultimate decision itself, which closely tracks the CCJ's perspective, has been particularly well received among jurists. ${ }^{213}$ Likewise, for every critic there are advocates who describe Caperton as "a welcome result for anyone interested in en-

208. N.Y. Times, People: Theodore B. Olson, http://topics.nytimes.com/top/ref erence/timestopics/people/o/theodore_b_olson/index.html (last updated Oct. 19, 2009) (noting, inter alia, that "[e]ven before Bush v. Gore, Mr. Olson long served as the leading appellate litigator of the Republican establishment").

209. Brief of the Conference of Chief Justices as Amicus Curiae Supporting Neither Party at 4, Caperton v. A.T. Massey Coal Co., 129 S. Ct. 2252 (2009) (No. 08-22), 2009 WL 45973 [hereinafter "CCJ Brief"].

210. Id. at 22.

211. Id. at 23.

212. $I d$.

213. See John Schwartz, Uncertainty in Law Circles Over New Rules for Judges, N.Y. Times, June 10, 2009, at A20 (citing Alabama Chief Justice Sue Bell Cobb's view that Caperton is a "'good thing' because it will push judges to be more careful"); Nathan Koppel, Massey Coal Ruling Getting Thumbs Up in Judicial Circles, WALL Sт. J. LAw Blog (June 8, 2009, 2:47 PM) http://blogs.wsj.com/law/2009/06/08/massey -coal-ruling-getting-thumbs-up-in-judicial-circles (noting, among others, Indiana Justice Randall Shepard's view that "it was wise of the majority to focus not just on the amount of a particular contribution ... but its size relative to the total amount of contributions"); see also Tony Mauro, Coping with Caperton, The BLT: THE BLOG OF Legal Times (June 10, 2009, 4:21 PM) http://legaltimes.typepad.com/blt/ 2009/06/coping-with-caperton-a-conversation-with-tom-phillips.html (quoting former Texas Chief Justice Tom Phillips' view that "Caperton established a principle that is really important: There are constitutional concerns with a judge sitting in judgment of a case where a party is a significant donor"). 
suring the fairness and integrity of the judicial decision-making process." 214 This is because, in large part, "the vast majority of the expenditures in Caperton were not direct contributions to the judge but rather were made by an independent group on the judge's behalf" 215 and yet, the court majority clearly-if ever so quietly-recognized as much.

There are, of course, salient differences between the ex post remedy of constitutionally mandated recusal due to independent expenditures, and upholding ex ante limits on the expenditures themselves. Writing for the Court in Citizens United, Justice Kennedy zeroed in on the distinction by noting that "Caperton's holding was limited to the rule that the judge must be recused, not that the litigant's political speech could be banned." 216 On its face, the statement is indisputably correct as a characterization of what Caperton did and did not address. It would, however, have been patently inappropriate for the Court to address the constitutionality of ex ante expenditure limits in Caperton-much less in state judicial elections generally-for numerous reasons, the most important of which was that no such limits were even remotely at issue in the case. Second, Justice Kennedy's reference to a "ban"--as opposed to contribution-like limits-is uniquely suited to Citizens United, which did involve a ban on expenditures, albeit one applicable only to expenditures from a very particular source-corporate and union general treasuries. ${ }^{217}$ By definition, expenditure limits allow more

214. J. Gerald Hebert, A Victory for Judicial Integrity from High Court, CAMPAIGN Legal Center Bloc (June 8, 2009), http://www.clcblog.org/blog_item-289.html (emphasis added).

215. Id.

216. Citizens United v. FEC, 130 S. Ct. 867, 910 (2010).

217. See, for example, id, in which the opening sentence of the opinion for the Court notes that "federal law prohibits corporations and unions from using general treasury funds to make independent expenditures." Many post-Citizens United discussions have involved more heat than light. Recent papers by Rick Hasen and Justin Levitt not only go against that grain, but offer compelling analyses of the decision and what can be reasonably anticipated to change in its aftermath. See Rick Hasen, Citizens United and the Illusion of Coherence, $109 \mathrm{MicH}$. L. REv. 581, 584 (2011) (noting that unusually broad language in Citizens United "will force the Court either to adopt a view that no limits on money in politics are ever constitutional or, more likely, to vote to sustain some limits [such as contribution limits] . . . through doctrinal incoherence"). Of particular pertinence to the thesis of this particular article, Hasen notes that due to the interplay of Citizens United and Caperton, the "Court's new doctrine is already incoherent" in that "[t] he Citizens United majority did not satisfactorily explain how independent expenditures, which apparently can not corrupt, were so corruptive, apparently corruptive, or distorting of a judicial election" as to lead to the result in Caperton. Id. at 584; see also Justin Levitt, Confronting the Impact of Citizens United, 29 YALE L. \& POL'y Rev. 
space for First Amendment interests than bans. In the judicial elections context, such limits also offer a reasonable ex ante mechanism for balancing the First Amendment against due process interests and the integrity of the courts. Far from undermining arguments for differential treatment of judicial elections, Citizens United underscores their very differences. The fact that Justice Kennedy writes the opinion for the Court in Citizens United as well as Capertonreflects, among other things, what was obvious all along-Justice Kennedy knows, very well, the difference, under Buckley, between expenditures and contributions, and found it appropriate to equate the concepts only in a case involving court elections. ${ }^{218}$

Finally, as the Conference of Chief Justices themselves noted in inviting the constitutional floor that the Court ultimately set in Caperton, going beyond that floor is part and parcel of "the state courts' legitimate constitutional role in protecting the due process rights of all litigants to fair and impartial trials in elective judicial systems."219 Accordingly, there could scarcely be a more appropriate arena for a classical state-as-laboratory Brandeis approach-including via the adoption of the "Caperton contribution" concept of reasonable expenditure limits in judicial elections.

(forthcoming 2010), available at http://papers.ssrn.com/sol3/papers.cfm?abstract _id=1676108 (noting, most pertinently, that Citizens United "flatly, and without empirical evidence, discounted [independent expenditure-based quid pro quo] exchanges as factual impossibilities," leading commentators to correctly note that "the Court's assessment contradicts its evaluation of very similar problems in Caperton").

218. Rick Hasen asserts that the Citizens United "majority's attempt to distinguish Caperton as a recusal case is unpersuasive" and posits, consistent with the thesis of this article, that he "suspect[s]" that Justice Kennedy believes that "independent spending does have the potential to corrupt, but that outside the context of judicial elections... the state's interest in preventing such corruption is outweighed by the considerable First Amendment costs of limiting such spending." Hasen, supra note 217, at 612 \& n.231. Professor Hasen, commenting in that article on a draft of this one, notes that while he agrees with the result in Caperton, he thinks "relabeling independent spending as a 'contribution' ... will only increase the incoherence of existing law," but on the substance of the arguments, we come down in exactly the same place. $I d$. at n.231. The terminology of "Caperton contributions" has, in my view, the attribute of capturing the concept in just two words, but Hasen is also rightly concerned with labels, given the Court's increasingly confounding campaign finance jurisprudence. See id.

219. CCJ Brief, supra note 209, at 14. 
IV. JUDICIAL CAMPAIGN EXPENDITURE LIMITS: AN
EXCEPTION BORN OF EXCEPTIONALISM

\section{A. The Due Process Interest in Limiting Judicial Campaign Expenditures}

In his 2008 year-end report on the federal courts, Chief Justice Roberts, writing in the context of making the case for salary increases for federal judges, unintentionally underscored the core concern at issue in Caperton and in any case in which a significant stakeholder is also a super spender-regardless of whether that spending is nominally on the expenditure side of the Buckley divide. According to Chief Justice Roberts, America's courts "guarantee that those who seek justice have access to a fair forum where all enter as equals and disputes are resolved impartially under the rule of law." 220 A judge generally has only two litigants before him or her. Consequently, from the standpoint of individual litigantseven in cases involving larger structural questions-what follows is almost always a zero-sum game: one litigant wins, and one loses.

A few commentators, including most notably Professor Karlan, have lamented that "fundamentally, Caperton continues the Court's problematic insistence on addressing structural problems through the lens of protecting individual rights." ${ }^{221}$ Similarly, Bob Bauer argues that Justice Kennedy used "the only constitutional tool in the kit, Due Process," and consequently "disguised a large public question as a private wrong, moving the resolution from any public political forum to the federal courthouse." ${ }^{222}$ The flip side of the allegedly "problematic insistence" is, of course, a necessary and healthy byproduct of the case or controversy requirement. The case arose in the context of the individual rights of Hugh Caperton and Harman Mining Company and the Court addressed it accordingly. Further, unfair adjudications, even for specific individuals or entities, pose a systemic risk to the legal system beyond the case at hand. If the public perceives, as it does, that justice is for sale, even if that is not true in all but the rarest of instances, then not only are

220. Chief Justice John G. Roberts, Jr., 2008 Year-End Report on the Federal Judiciary 7 (Dec. 31, 2008), available at http://www.supremecourt.gov/publicinfo/ year-end/2008year-endreport.pdf.

221. Pamela S. Karlan, Electing Judges, Judging Elections and the Lessons of Caperton, 123 HaRv. L. REV. 80, 81 (2009).

222. Bob Bauer, Kennedy's Problem in Caperton v. Massey and the Unfortunate Solution He Chose, MORE SOFt Money Hard LAw Web Updates, (June 12, 2009) http://www.moresoftmoneyhardlaw.com/updates/the_supreme_court.html?AID= 1453. 
individual litigants aggrieved, but the public's faith in the rule of law is severely undermined.

Structurally, the core role of the courts, as distinct from the legislative and executive branches, is to manifest the one branch of government where all-spenders and non-spenders alike-enter as equals under law, and where the public perceives as much. There can be no doubt, however, that monetary influence, in addition to its systemic challenges, also undermines the due process rights of individual litigants. Consequently, where states fail to include ex ante safeguards to address the concern systemically, ex post remedies like recusal are inherently and wisely focused-as Caperton was-on individual rights.

Just as importantly though, the individual rights frame is what gives judicial campaign finance its special flavor. Inherently, the protection of individual rights is a decidedly non-trivial matter to the aggrieved individuals who may "enter as equals," but who enter the courtroom to face an adversary who spent millions supporting the campaign of the jurist who will decide their case. Moreover, in the courts context, the protection of a structural procedural rightto a hearing before an arbiter who is and objectively appears to be impartial-is patently absent in the constituent-based branches.

It is this individual-right-as-structural-right dynamic that Ted Olson captured in rebuttal during the oral argument before the Court. Massey's counsel Andy Frey implicitly encouraged the Justices to empathize with Justice Benjamin's perspective; correspondingly, these Justices would see his refusal to disqualify through the filter of their own faiths in their own respective commitments to impartiality. Frey asked the Justices the following rhetorical question during the argument: "[I]f you were in Justice Benjamin's situation, do you really think you would be incapable of rendering an impartial decision in a case involving Massey? Because if the answer to that is no ... then there's no justification for saying that Justice Benjamin would."223 Moments later during rebuttal, Olson deftly reframed the issue, encouraging the Justices to see the issue from the perspective of the individual litigant. In so doing, Olson was also implicitly drawing on the notion that the right the individual is seeking is, in fact, the most fundamental structural characteristic distinguishing the courts from the legislative and executive branches:

Would a detached observer conclude that a fair and impartial hearing would be possible? So instead of the question that Mr.

223. Caperton Transcript, supra note 176 , at 41 . 
Frey was asking ... I would like to ask you to ask this question. If this was going to be the judge in your case, would you think it would be fair and would it be a fair tribunal if the judge in your case was selected with a $\$ 3$ million subsidy by your opponent? ${ }^{224}$

Speaking at a September 2009 conference on state courts, hosted by Justice O'Connor, First Amendment scholar Kathleen Sullivan opened her remarks by indicating that, in her view, "the [Caperton] case was . . . a no-brainer ... [and that] given all the particular facts and optics in the case, Justice Benjamin should have recused himself under the West Virginia standard or the ABA standard and it should have been an easy matter that didn't have to go to a Due Process ruling." 225 Like Olson, Sullivan is generally opposed to campaign finance regulation, ${ }^{226}$ making her strong support of the decision in Caperton further evidence that judicial election restrictions are different. For Olson and Sullivan, opposition to most campaign limitations on First Amendment grounds, but support for broader limits in the judicial election context, is a principled juxtaposition. The position embraces the fundamental premise-disputed by those on the fringes-that judicial elections really are and ought to be different from legislative and executive races in constitutionally meaningful respects. To that end, it is worth noting that Olson argued both Caperton and Citizens United before the Supreme Court. Moreover, Justice Kennedy, who wrote opinions for the majority in both cases, agreed with his perspective on each occasion. ${ }^{227}$

224. Id. at 55-56.

225. Kathleen Sullivan, Professor, Stanford Law School, One Symptom of a Serious Problem-Caperton v. Massey, Address at the Seattle University School of Law (Sept. 14, 2009), available at http://medialaw.seattleu.edu/events/judicial/; see also Sample, supra note 12, at 294. While Benjamin's failure to disqualify himself under the rules proved so egregious as to become a constitutional case, less compelling scenarios put judges in a tough position. Indiana Professor Charlie Geyh, who has ably spearheaded an $\mathrm{ABA}$ project on recusal, recently testified before Congress that "judges who are deeply committed to the appearance and reality of impartial justice are called upon to acknowledge, in the context of specific cases, that despite their best efforts to preserve their impartiality, they are partial or appear to be so." Examining the State of Judicial Recusals After Caperton v. A.T. Massey: Hearing Before the Subcomm. on Courts and Competition of the H. Comm. on the Judiciary, 111 th Cong. 2 (2009) (statement of Charles G. Geyh, Associate Dean of Research, John F. Kimberling Chair in Law, Indiana University Maurer School of Law at Bloomington), available at http://judiciary.house.gov/hearings/pdf/Geyh091210.pdf.

226. See infra note 228 and accompanying text.

227. See Caperton v. A.T. Massey Coal Co., 129 S. Ct. 2252 (2009); Citizens United v. FEC, 130 S. Ct. 867 (2010). 
The significance of Professor Sullivan's comments was largely lost on the national legal establishment. However, the comments raised the eyebrows of at least one campaign finance scholar, Rick Hasen, who was a fellow panelist with her in Seattle. Blogging about the conference, Hasen noted that "[i]t was a somewhat surreal experience to sit next to Kathleen (usually an ardent opponent of campaign regulations aside from disclosure) [and] to hear Kathleen call for consideration of a ban for everyone on independent spending in judicial campaigns . . . "228 Most pertinently for the purposes of this article, Sullivan's "call" included the following:

The question, I think, that's relevant for us to think about . . is what latitude is there for trying to impose more ex ante limits on the kind of judge buying that occurred, that led to the Caperton ruling. Now, I strongly support First Amendment limits on expenditure limitations in the political campaign context, but I think there is no reason to think they apply exactly the same way in judicial election contexts. ${ }^{229}$

Long prior to Caperton, the Court had recognized that "[a] fair trial in a fair tribunal is a basic requirement of due process." 230 More than half a century ago, the Court articulated what it described as the "stringent rule" that to "perform its high function in the best way justice must satisfy the appearance of justice" even though such a rule "may sometimes bar trial by judges who have no actual bias and who would do their very best to weigh the scales of justice equally between contending parties."231 Taken at face value, such a proposition is hardly controversial. Applying it is a much more difficult task. Accordingly, the Court had also recognized the "fundamental tension between the ideal character of the judicial office and the real world of electoral politics[.]"232

Testing this "tension" in White, Justice Scalia's opinion for the Court took pains to include the caveat that the Court was neither asserting nor implying that the "First Amendment requires campaigns for judicial office to sound the same as those for legislative office." ${ }^{233}$ The Scalia opinion included a significant exposition on due process, in which it found that while candidate announcements

228. Rick Hasen, Sandra Day O'Connor: End Judge Elections in Wash., Election LAW BLOG (Sept. 15, 2009, 8:17 AM), http://electionlawblog.org/archives/ 2009_09.html (emphasis added).

229. Sullivan, supra note 225.

230. In re Murchison, 349 U.S. 133, 136 (1955).

231. Id. (internal quotations omitted).

232. Chisom v. Roemer, 501 U.S. 380, 400 (1991).

233. Republican Party of Minn. v. White, 536 U.S. 765, 783 (2001). 
relevant to issues were protected speech, preventing bias for or against particular parties is essential under the Due Process Clause. ${ }^{234}$

Seven years after White, for all the falderal over its sensational and extreme facts, Caperton (despite its somewhat narrow holding) gave teeth to the protection of the specific aspect of due process that White endorsed. Whatever First Amendment interest a litigant or counsel has in contributing or spending in a campaign, she has no constitutionally protected interest in gaining an unfair litigation advantage on that basis. In so holding, Caperton adds muscle to the Court's earlier articulations of judicial independence boilerplate. Moreover, the fact that the Court's action came in a circumstance where, indisputably, the spending that created the "serious risk of actual bias-based on objective and reasonable perceptions" 235 was almost entirely expenditure-based rather than contribution-based is all the more remarkable.

\section{B. Expenditure Limits and the Equality Rationale}

Professor Roy Schotland recently captured the essence of the decision's broader ramifications, asserting simply that "Caperton's fundamental holding is that judicial elections are different. One cannot conceive of a court holding that a legislator (or executive) would be barred from acting in $\mathrm{X}$ matter because a campaign supporter was involved."236 Schotland is correct on both counts. Viewed through a campaign finance lens, "Caperton contributions" embody these differences.

The case for regulating both contributions and expenditures in judicial campaigns is not only compelling but also urgently necessary to prevent a developing constitutional crisis. First, the core "Schotland" difference distinguishing even elected judiciaries from the constituent branches is one such compelling indicator of the need for regulation. Second, the Supreme Court has never specifically addressed the constitutionality of limits on independent expenditures in judicial elections. Third, judicial campaign spending has exploded since Buckley and particularly in the last decade and with respect to independent spending and the "super-spender" dynamic. Fourth, as Erwin Chemerinsky has noted, Buckley "did not create an absolute bar to government regulation of expenditures"

234. See id. at 775-77.

235. Caperton v. A.T. Massey Coal Co., 129 S. Ct. 2252, 2263 (2009).

236. Roy A. Schotland, Caperton Capers: Comment on Four of the Articles, 60 SYrACUSE L. Rev. 337, 344 (2010). 
but "rather, it imposed strict scrutiny as the test that must be met." ${ }^{337}$ Fifth, as Kathleen Sullivan asserts, White is "a very narrow decision" and "lower courts that have interpreted White broadly have gotten White wrong" because they "ignore the countervailing interests of a constitutional magnitude that are implicated by limiting the expenditure or the contribution of funds and the use of those funds in judicial campaigns." 238 Sixth, Sullivan correctly recognizes that "nothing in White ruled out the possibility that those countervailing constitutional interests could trump whatever free speech interest there might be in a particular case."239 Given this combination of factors, Justice Kennedy's silent but clear equation of independent expenditures and contributions in the judicial elections context, leading to the concept that this Article coins as "Caperton contributions," guides the way forward for one of the best available ex ante means of preserving the actual and perceived integrity of the nation's state courts.

Judge Guido Calabresi, concurring in the Second Circuit's 2005 denial of rehearing en banc in Landell $v$. Sorrell, stated bluntly that the failure to address inequality concerns "has been, since Buckley, the huge elephant-and donkey-in the living room in all discussions of campaign finance reform." 240

In his admirable-and unsuccessful-push for rhetorical realism, Judge Calabresi's words echo those of Judge Skelly Wright. As part of the ultimately overturned D.C. Circuit panel in Buckley itself, Judge Wright later lamented that "the dominance of wealth in the political process is inconsistent with both the philosophical meaning and the practical exercise of political equality." ${ }^{411}$ Judge Wright buttressed his perspective with that of no less than political philosopher John Rawls, who asserted simply that the "liberties protected by the principle of participation lose much of their value whenever those who have greater private means are permitted to use their advantages to control the course of public debate."242 Ronald Dwor-

237. Chemerinsky, supra note 39 , at 134.

238. See Sullivan, supra note 225 (detailing three such "major" countervailing interests: (1) the rule of law; (2) separation of powers; and (3) the individual litigant's interest in due process) (emphasis added).

239. Id. (noting other countervailing interests that have been found compelling enough to "overwhelm" the speech interest in the Hatch Act cases).

240. Landell v. Sorrell, 406 F.3d 159, 162 (2d Cir. 2005) (Calabresi, J., concurring in the denial of rehearing en banc), rev'd sub nom., Randall v. Sorrell, 548 U.S. 230 (2005). The Second Circuit initially upheld, but then the Supreme Court struck down several provisions of Vermont campaign finance law.

241. Wright, supra note 52, at 629 .

242. Id. at 630 (citing John Rawls, A Theory of Justice 225 (1971)). 
kin is more direct, asserting that "[o]ur politics are a disgrace and money is the root of the problem." 243

Calabresi, Wright, Mills, and Dworkin are, of course, contemplating rules applicable to non-judicial campaigns. Suffice it to say, their sentiments apply a fortiori to campaigns for offices that, unlike the constituent-based branches, manifest the highest ideals of equality under law.

\section{V. \\ CONCLUSION}

In a short essay published in 1998, just prior to the proliferation of judicial campaign spending described in this Article, Dean Chemerinsky asserted that "only limits on both contributions and expenditures can succeed" in the task of preserving "an independent judiciary and public confidence that one exists." 244 Acknowledging that "expenditure restrictions limit political speech," Chemerinsky asserted that "this is constitutional because it is the only apparent way to achieve an undoubtedly compelling interest: preserving an independent judiciary in the face of the corrosive effects of ever larger spending in judicial elections."245

Paradoxically, it is both regrettable and fortunate that Dean Chemerinsky's assertion is exponentially more powerful today than it was barely more than a decade ago. Regrettable because in terms of the sums at issue, the threats to impartial justice, and the public's growing perceptions of same, the differences of a decade are differences not of degree, but in kind. Fortunate too though, because Caperton makes clear that judicial elections are manifestly-rather than merely rhetorically-different from legislative and executive campaigns in constitutionally meaningful respects. Judicial elections-for some a bright spot, for others a backwater of American exceptionalism-are for better or worse, here to stay. Caperton points a way forward. It demonstrates that the rejection of strict path dependency-based on campaign finance jurisprudence pertaining solely to the political branches-is now not only settled constitutional law, but also sound public policy.

This Article saves for future discussions, and hopefully for the states as laboratories, debates regarding the merits of particular

243. Ronald Dworkin, Free Speech and the Dimensions of Democracy, in If Buckley Feli: A First Amendment Blueprint for Regulating Money in Politics 63 (Josh Rosenkranz ed., Century Foundation Press 2000).

244. Chemerinsky, supra note 39, at 149.

245. Id. 
proposals involving spending-as opposed to merely contribution-limits in judicial elections. To be sure, all such proposals will involve tradeoffs and "hydraulics" 246 of their own. Also to be sure, it is clear-in part because of campaign hydraulics-that spending limits are just one of the multi-prong measures needed to protect the courts from what Justice Sandra Day O'Connor bluntly calls the "wrong" of "cash in the courtroom."247 In addition to limits on expenditures-which, like contribution limits are prohibitions only in excess of trigger thresholds-other ex ante measures such as voluntary judicial public financing systems promote a vibrant political discourse while also respecting the "countervailing concerns of constitutional dimension" 248 that are applicable to the courts.

Inevitably, even the best ex ante measures, including spending limits, will be imperfect. Like any preemptive effort, they will invariably fail to anticipate every scenario that circumstance, chance and intent can conceive. Fortunately, because the vast majority of state court jurists are deeply committed to preserving the integrity of their courts, only the rarest exceptions ever morph into a one-person Constitutional crisis on the scale of Justice Benjamin.

When, however, a jurist acts unilaterally and subjectively against the clear weight of objective perceptions, ex post measures such as strengthened procedures to enforce non-constitutional recusal rules are an effective and important fairness protection. ${ }^{249}$ Spurred by Caperton, in 2010, the state of Michigan enacted just such a process -one that, if it had applied in West Virginia, would have prevented Caperton from ever turning into a federal constitutional case. Michigan Chief Justice Marilyn Kelly spearheaded the court's adoption of the new process in large part because, in her words, it "permits a justice's recusal where that justice is unable to

246. See Issacharoff \& Karlan, supra notes 40.

247. Dorothy Samuels, Op-Ed., The Selling of the Judiciary: Campaign Cash 'in the Courtroom, N.Y. Times, Apr. 15, 2008, at A22.

248. Sullivan, supra note 225; see also North Carolina Right to Life Comm. Fund for Indep. Political Expenditures v. Leake, 524 F.3d 427, 441 (4th Cir. 2008) (upholding North Carolina's judicial public financing system and stating that "the concern for promoting and protecting the impartiality and independence of the judiciary is not a new one; it dates back at least to our nation's founding .... [T] he provisions [of North Carolina's public financing system for judicial campaigns] challenged today, which embody North Carolina's effort to protect this vital interest in an independent judiciary, are within the limits placed on the state by the First Amendment").

249. Caperton is already spurring halting but positive progress in the area of court reform, particularly in the area of recusal, a dynamic I describe at length in James Sample, Court Reform Enters the Post-Caperton Era, 58 Drake L. REv. 787 (2010). 
render an unbiased decision and unable or unwilling to acknowledge that fact." ${ }^{250}$ Chief Justice Kelly noted further that the "justice system and this Court can only be stronger for it."251

Scholars have long debated whether and to what degree overturning or modifying Buckley's contribution-expenditure distinction would improve the quality, and perhaps even the quantity, of American political discourse. While I concur with Professor Neuborne's belief that free speech values "would be advanced, not endangered, by the placement of generous ceilings on campaign spending," 252 in judicial and non-judicial elections alike, that, manifestly, is a controversial question on which principled people reasonably disagree. This Article posits a more modest and potentially more broadly acceptable proposition: given compelling state interests in an impartial and independent judiciary, expenditure limits in judicial elections meet strict scrutiny, and appropriately balance the First Amendment with due process and structural concerns of equally important constitutional magnitude.

Even those members of the legal community-ranging from Ted Olson and Kathleen Sullivan to Justice Kennedy-who traditionally believe that campaign regulation in the constituent branches unconstitutionally infringes on the First Amendment recognize the compelling countervailing interests applicable in judicial elections. Notably, Justice Kennedy's equation of contributions and expenditures is a refreshing rejection of Buckley formalism in the manifestly unique context of campaigns for the bench. Caperton provides a solid constitutional foundation for expenditure limits in judicial elections. If adopted, particularly in a post-Citizens United era, such limits would substantially reduce the risk of the "mutually assured destruction" in our courts of which Justice O'Connor so wisely warns.

250. Id. at 807 (citation omitted).

251. Id.

252. Burt Neuborne, Soft Landings, in If Buckley Fell: A First Amendment Blueprint for Regulating Money in Politics 184 (Josh Rosenkranz ed., Century Foundation Press 2000); see also Neuborne, supra note 14, at 14 ("It remains to be seen whether the same assumption-that all limits gravely injure the quantity of political speech-would be justified in the context of more generous spending ceilings."). 